This list is intendeg to be of assistance to home owners, home builders, and others interestgd in materials, equipment, and practices employed in the constmution of dwellings and in the maintenance and modernization of home properties. It includes pubitcations issued by the Federal Government and by national trade associations and other organizations in which materials, equipment, and recomended methods. of applying or installing them are described. The National Bureau of ... Standards, however, cannot assune responsibility for statements made in outside publications by others than nembers of the Bureau staff.

In addition to the sources menticned in the list, many universities and colleges, through their engineering and experinent stations, agr.cultural extension divisions, and other defartmentis, publish pamphieus of interest, to home owners. A list of these institutions by States is given on page 33 of this parphlet.

The Federal Government prabicaticns, where prices are shown, may be obtained from the Superinterdent of Documents: vernment Printing Office, Washington, D. C. The prices guotsd are for deij.very to addresses in the United states and its tertitories ana possessions, and in certain foreign countries whin w: itend the franting privilege. For all other countries one-tind tile cosi of the publication should be added to cover postage. Prepaymenti is requirec and should be made either by coupons cotainable from tice supexintendint of Documents in sets of 20 for $\$ 1,00$ and good until used or by checz or money order payable to the Superintendent of Documents, Governinent Printing Office, Washinston, D. C. Do not remit in posiage stamps. Any publication listed as "free" may be obtained without charge from the Department issuing it. 
The publications of the Waticnal Bureau of Standards have been issued in several series, indicated on this list by their initials:

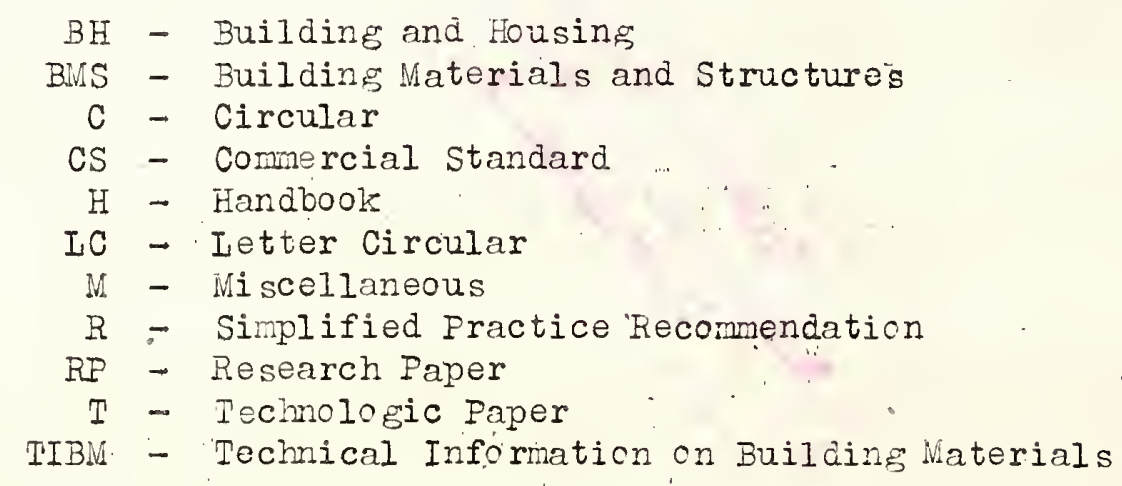

Publications prepared by the trade associations and other organizations listed herein hay be procured by writing to them at the addresses given. 
DEPARTMENT OF AGRICULTURE

Washington, D. C.

Adobe or sun-dried brick for farm buildings

(Famerst Bulletin "No. "it20).............. 5 cents

DEPARTMENT OF COMMERCE (National Bureau of Standards).

Washington, D. C.

Compressive strehgth of sand-lime brick walls (T276)..... 10 cents

Water permeability of masonry wall.s. (BNS-7) ............ 10 'f

Water permeability of walls built of masonry units (BMS-82) 20" "I

Face brick, rough and smooth; comon brick (R7) ......... 5 "

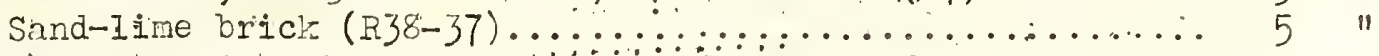

Recomended minimun requirenents for small dwelling

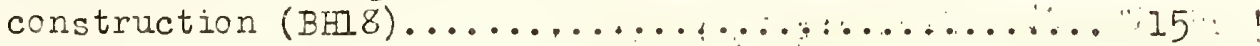

Structural, heat-transfer, and water-permeability:..... properties of five earth-wall constructions'(BMS-78). 20 "

Exterior waterprofing for másony (TIBM-5) ........... Free

Weathering properties of building brick (TIBiv-57)........"

Tests of cement-water paints and other waterproofings

for unit-masonry walls $(B M S-95) \ldots \ldots \ldots \ldots \ldots \ldots \ldots$ cents

DEPARTMENT OF THE INTERIOR (Office of Indian Affairs)

Chiloccc Indian School, Chiloces, Orlahoma

Earth brick constructicn....................... 50 cents

Structural Clay Products Institute

$1756 \mathrm{~K}$ St., N. T., Washington, D. C.

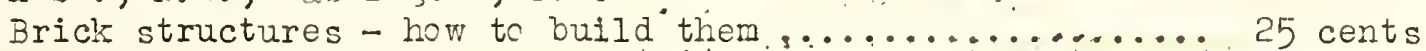

Your home - of burned cláy màsonry ................... 15 "

Waterti jhtness and transverse strength of masonry walls... 10 "

\section{CHINNEYS AND FIREPIACES}

DEPARTMENT OF AGRICUITURE

Washington, D. C.

Fireplaces ard chimneys

(Farmers' Bulletin No. 1889).

10 cents.

Eastern Clay Products Association

906 Colonial Bldg., Philadelphia, Pa.

Flues and flue linings with related data on.

chimeys and fíreplaces.

Free 
National As sociaticn of Stove hanufacturers

P. O. Station B, Buffalc, N. Y.

Extracts from various publications respecting

chimreys, drafts, etc.'.

10 cents

National Board of Fire Underwriters

85 John St., New York, N.Y.

A. standard ordinance for chimey construction........... Free

Naticnal Fire Protecticn Associaticn

60 Batterymarch St:; Boston; Wass.

Chimneys, flues and fireplaces; how to build ther........ Free

Make your chimeys safe.........................." "

Structural Clay Products Institüte

1756 K S. St.., ì. W. Washington, D. C.

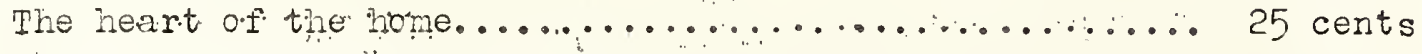

\section{CLAY PRODUCTS}

(Tall tile-Sever pipe)

DEPARTMENT OF COMMERCA (National Bureau of Standards)

Washington, . D. C. .....

Clay tiles for floors and walls (R61-44) (Mimeographed)... Free

Eastern Clay Froducts Association

906 Cclonial. Bl.dg.', Philadelphia, $\mathrm{Pa}$

Standards.

Free

The Tile Manufacturers Associaticn, Inc.

50 E. 42nd St., New York, N. Y.

Basic specification for tilework, $\mathrm{No}, \mathrm{K}-3 \mathrm{CO}, \ldots \ldots \ldots \ldots . .$. Free

Facts about tile............................" "

\section{COS CRITE}

DEPARTMENT OF AGRICULTURE

Washington, D. C.

Use of concrete on the farm

(Famers' Bulletin No. 1772)................ 10 cents 
DEFARTMENT OF COMMERCE (Naticnal Bureau of Standards)

Washington, D. C.

Recommended inimum requirements for small dwelling.constructicn. (BH 8 ).

15 cents

Recomended building code requirenents for new dwelling construction with special reference to

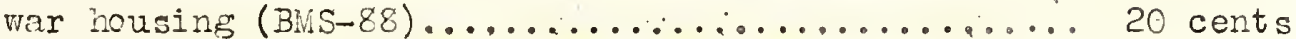

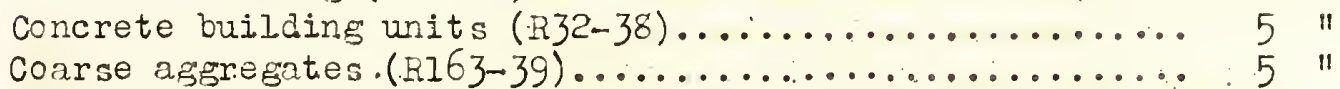

Intejral, waterproofins for concrete $($ IBM-6) ........... Free

Water permeability and weathering resistance of stucco-faced, gunite-faced, and "Knap concreterunit".

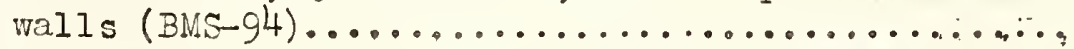

Tests of cement-water paints and cther waterprcofings

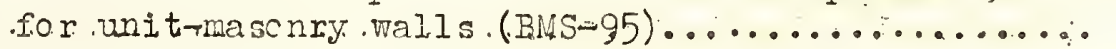

Calcium chloride as it affects portland cenent

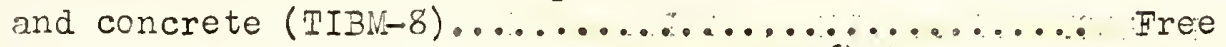

Concrete and reinforced concrete (Iist) (IC 642).............. FIDERAI HOUSING ADMINISTRATION (Technical Division)

Washirigton, D. C......

Reinforced concrete construction (Circular No. 3)....... Free

American concrete Institute

7400 Second.BIvd., Detroit, Mich. .

A. C. I. Manual of Concrete Inspection...............\$1,00

Concrete Reinforcing Steel Institute

Builders Building, Chicago, Ill.

Reinforced cencrete: a manual of standard practice........ Free

Douglas Fir PlywQc Asscatich

Tacoma Blds., Tacoma, Wash.

Concrete forms $\wp f \cdot$ Douglas fir.plywcod............... Free

Naticnal Sand.and.Gravęl. Asseciaticn; Inc, :

Munsey. BldE., . Washingtẹ., D. C.

Estinating quantities of materials for concrete

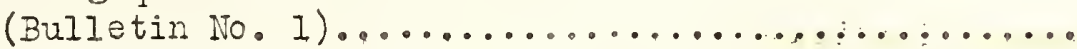

Tables of quantities of materials for concrete

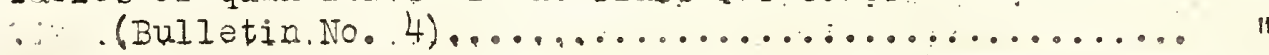

Proparticning concrete mixtures (Circular. 21)............

Portland Cement Association

33 T. Grand Ave., Chicago, IIl.

Facts. about concrete ma sonry................... Free

Concrete. facts. for concrete contractcrs................" 
DEPARTMENT OF AGRICULTURE

Washington, D. C.

Electric lisht for the farmstead

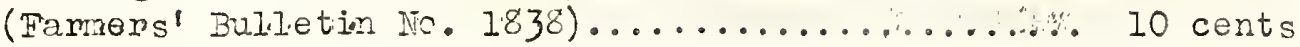

DEPARTMENT OF COMMEREE (Natînal Bureau of Standards)

Washington, D. C.

Safety rules for the installation and maintenance :

of electric utilization equipment ( 133$) \ldots \ldots \ldots \ldots \ldots \ldots \ldots \ldots \ldots \ldots$ cents

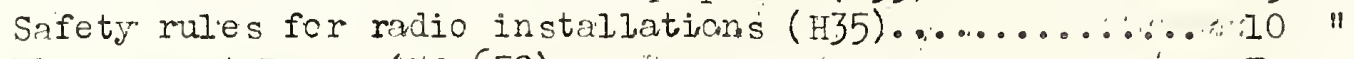

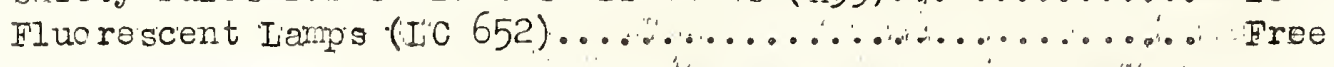

FEDERAI HOUSING ADMINISTRATION

Tashineton, D. C.

Nechanical equipment, for':the home

(Technical Bullatin ivo.6)

5 cents

RURAI ELECTRICIFICATION ADMINISTRATION

Washington, D. C.

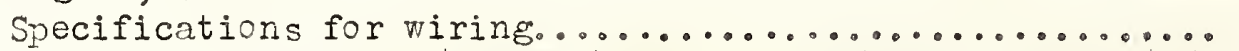

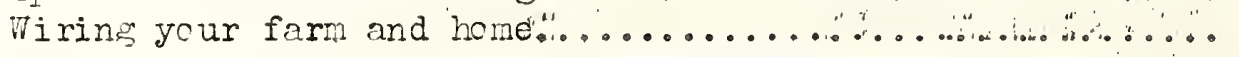

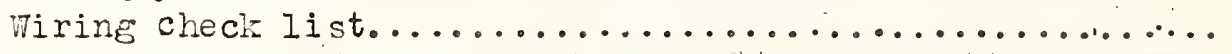

Free

"I

$\| \cdot$

TENDESSEE VALIEY AUTHORITY (Information Office)

Knoxville, Tenn。

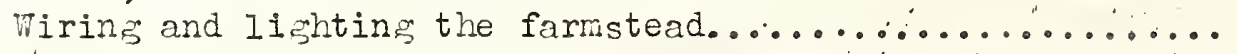

Rural electrificaticn for the home..

40 cent s .50. 11

Better Homes in America.

Purdue Research Fcundation, Test Iafayet te; Ind.

Planning the electrical installation for greater

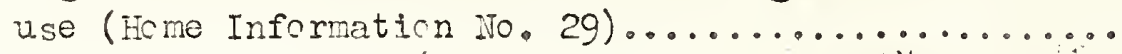

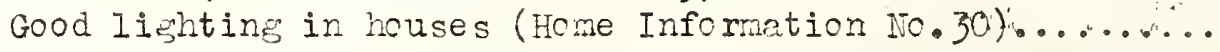

15 cents

15 "

Comittee on the Relation of mlectricity to Agriculture:

58 E. Washington.St., Chicaso, IIl.

Wiring the farm for light, theat, and power............ 50 cents

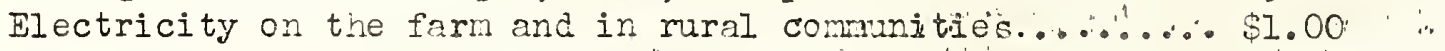

Edisan Eleotric Institute

420 Lexington Ave, Niew York, N. Y:

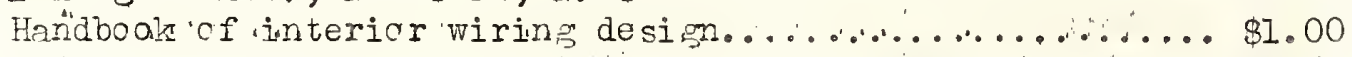

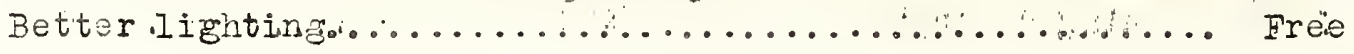

Naticnal Adequate Wiring Bureau.

$155 \mathrm{E}, 44 \mathrm{th}$ St., New York, N. Y.

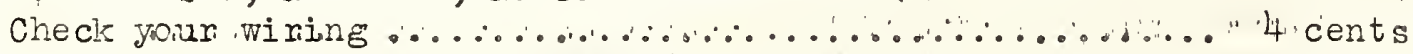

National, specifieation for residental wiring............ I0 .

Arcitects specifications for adequate home wiring...... 10 "

National Board of Fire Underwriters

85 John St., New York, N. Y.

National electrical code.

5 cents 
Facific Coast Electrical Bureau

447 Sutter St., San Franciscc, Calif:

601 w. 5th st., Ics Anjeles, Calif.

A free service (wiring) (onlifornia only)............. Free

Underwriters' Laboratoriès, "Inc.

207 E. Ohic St., Chicago, IIl.

List of inspected electrical equipment.............. Free

\section{FINANGING.}

FEDERAL HOUSING ADMINI STRATION

Washington, D. C.

The FHA plan of home ownership (FHA 2098)

Free

Snail homes on the FHA pian (FHA 858).

Illustrative case' (FA 2042 )

10 cents

Better Hones in Americà

Purdue Kesearch Foundaticn, West Lafayette; Ind.

Financial aspects of home ownership

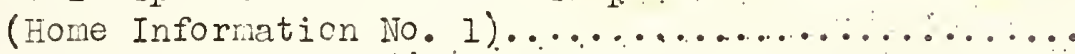

15 cents

\section{FIRE PREVENTION AND FIRE PEOTECTION}

DEPARTMENT OF. AGRTCULTURE

Washington, D. C.

Frotection of buildings and farm property from

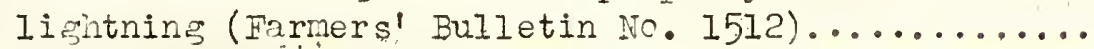

Fire-protective construction on the farm

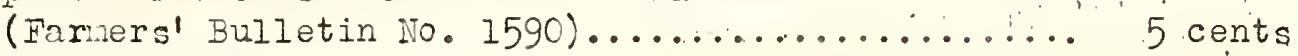

DEPARTIENT OF COMNERCE (National Bureau of Standards)

Washington, D.. C. .

publications relating to fire resistance and fire

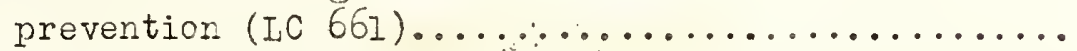

Recommended minimum requirements for fire resistance

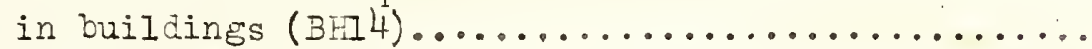

Fire-resistance classifications of building

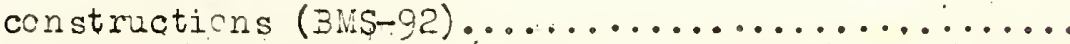

Fire tests of wocd- and metal-framed partitions (BMS-71).

Free

10 cents

$25 \quad n$

20 "


Gypsum As sociation

211 W. Wacker Drive, Chicaşo, III.

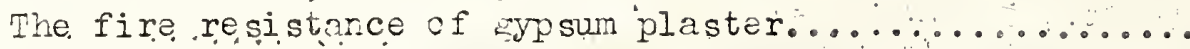

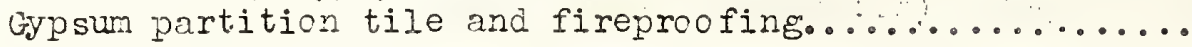

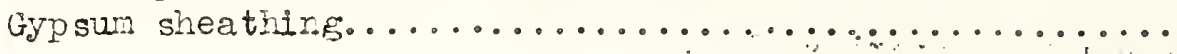

Frée

II

Metal Iath Manufacturers Association

208 s. Ia Salle sto, Chicago, IIl.

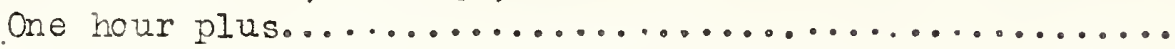

Free

Fire retardant properties of various partitions (in

Partiticn Handbook)

$\$ 1.00$

Naticnal Board of Fire Underwriters

85 John St, , Mew York, N. Y.

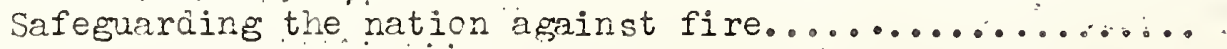

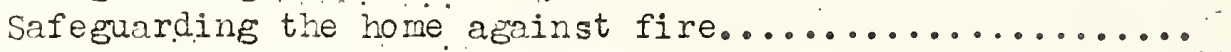

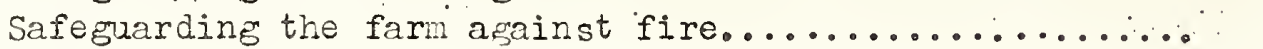

Nature's artillery (Ii hintning protection)............"

Naticnal Fire Protection Ássociation

60 Bat terymarch St.., Boston, Mass.

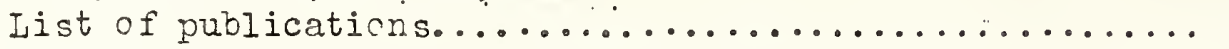

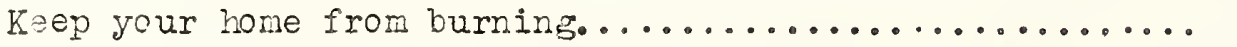

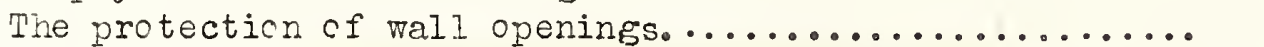

Protect your property against lightning..............."

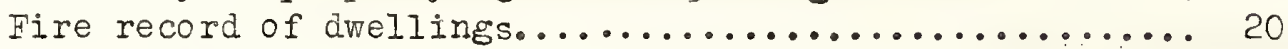

Free

0 cents

Steal Joist Institute

201 No. Wells. St, , Chicazo, III.:

Fire resistance of open-web steel joist construction....

Free

Underwriters' Laboratories, Inc.

207 E. Ohio St., Chicago, IlI.

I,ist of inspected fire protection appliances........... Free

\section{HIOCIS AND TALES}

DEPAETMEITT OF AGEICULURT

Washington, D. C..

Preventing cracks in new wiod floors (Leaflet No. 56).... 5 cents

Selection, installation, firish, and maintenance of wood

floors for dwellings (Circular No. 489)...........

511

DEPARTMENT CF COMMERCE (Bureau of Fo reign and Domestic Commerce) Washineton, D. C.

American hardwood flocring. and its use

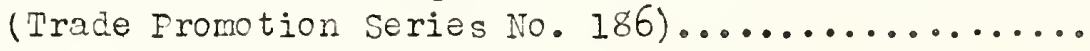

10 cents 
Washington, D: C.

Indentation Characteristies of' Flocr. Goverings (BMS-73)... 10 cents

-.. Indentation and recovery of low-cost flcor covering

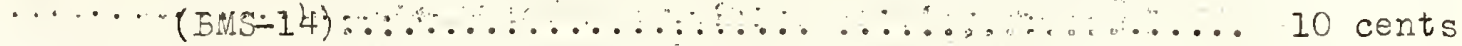

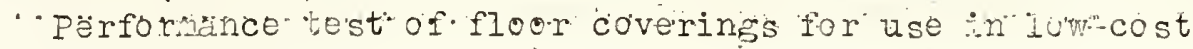

…..... housingo

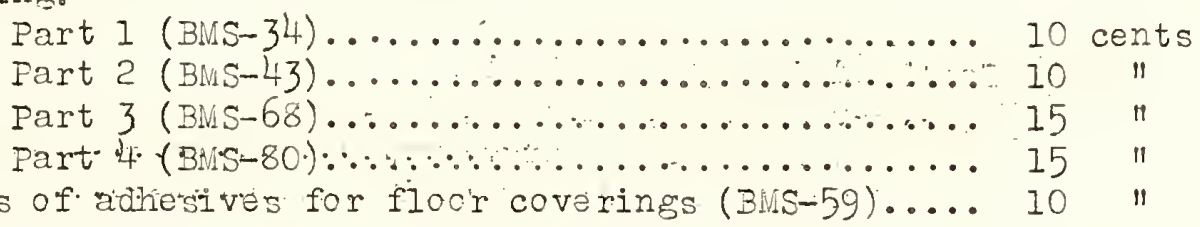

Froperties of adhesilves for filocir coverings (BMS-59).... 10 "

Dimensional changes of floor coverings with changes in relative humidity and temperature (BMS-85)........ 10 cents Relative slipperiness of floor and deck surfaces (BMS-100) 10" Rubber floor tile (IC 270). ....................... Free

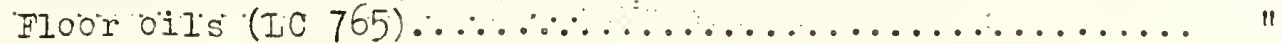
Finislies for concrete floors (IC 758)..............."

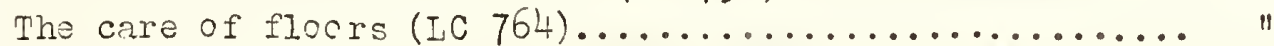

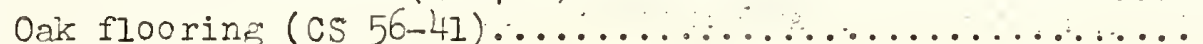

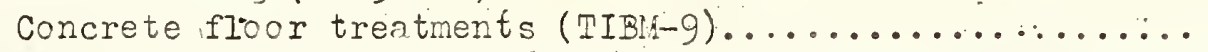
késistarice of Ploor ccvering materials to staining and chemicals $(T I B M-52) \ldots \ldots \ldots \ldots \ldots \ldots \ldots \ldots \ldots$.

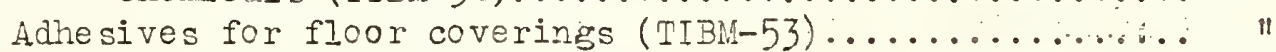
Relative resistance of floor covering materials to 'abrasion (TIBM-54), $\ldots \ldots \ldots \ldots \ldots \ldots \ldots \ldots \ldots$

5 cents Free

"

Gypsum Association

211 W. Wacker Drive, Chicago, III.

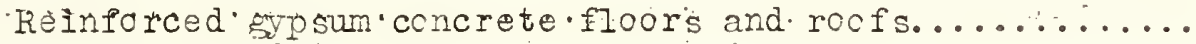

Maple Flcoring Manufacturers Association

1740 McCcrmick Bldg., Chicago, IIl.

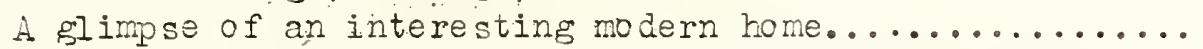

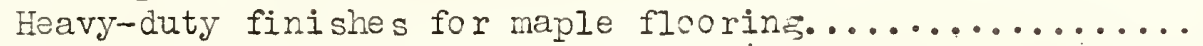

Northern hard maple beech and birch flocring ...........

Naticnal Oak Flooring Nanufacturers Association

830 Dermon Blds., Nemphis, Tenn.

How to lay, finish and care for NOFMA oals flociö........

specification manual for certified oak floors...........

Free

II

Naticnal Slate Assocation

325 E. 57 th st., New York, N. Y.

The charm of slate flcors and walks.
Free

Free

11

$\|$
Free 
The National Terrazzo and Mosaic Association, Inc:

1420 New York Ave., N. W., Washington, D. C.

Specifications for'terrazzo work and for mo saics........ Free

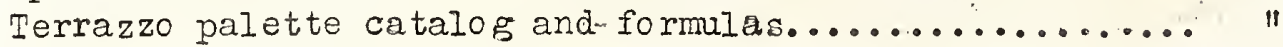

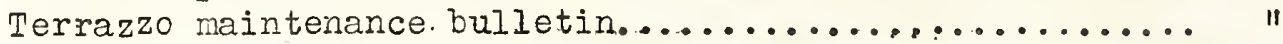

Divider $\operatorname{strip}$ Iocation and data......................

Portland Cement Association. . . ....

33 W. Grand Ave., Chicago., Ill.

Concrete sidewalks........................... Fres

Concrete floors for residences................... "

The Rubber Vanufacturers Association, Inc.

444 Madi.son-Ave. , New York, N. Y.

Standard specifications and approved method for installing rubber ti.l.e floc.ring...................... Free Approved maintenarce methods for rubber floors......... If

Southern Cypress Manufacturers Association

Barnett Naticnal Bank Bldgs, Jacksonville, Fla.

Pecky cypross blocks for garden walks................ Free

Southern Pine Association.

Canal Building, New Orleans, La.

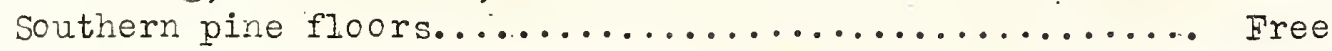

Steel Joist Institute

201 N. Wells St., Chicago, IIl.

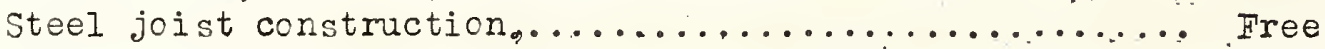

Open-web. steel.joists for floors and roofs............." "

\section{GARALE CONSTRUCTION .}

Portland Cement Association

$33 \%$. Grand.Ave; Chicago, IIl.:

The home garage of concrete masonry.................. Free

Southern Pine Association

Canal B1ds.., New Orleans, La."

southern pine garages and how to build them............ 25 cents

GAS.

$\ldots \ldots \ldots \ldots \ldots$

DEPARTIENT OF COMNECE (National Bureau of Standards)

Wa shinston, D. C.

Desich of sas burners for domestic use (c394).......... 10 cents

Cauticns regarding jas appliance attachments (C404)..... 5.". . 
DEPARTMENT OF THE INTERIOR (Buneau of Mines)

Washington, D. C.

- Natural-gas manual for the home

(Mines Technical Paper Iro... 3205.)

10 cents

American Gas Association

420 Lexington Ave., New York, IT. Y.

Do ycu know? (Gas appliance facts).................. Free

Gas range service manual........................\$1.00

Pacific Coat Plumbing Inspectors' Association

4733 Templeton St., Ios:Angeles, Calif.

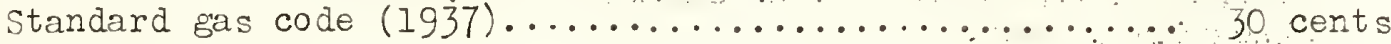

Underwriters' Laboratöries, Inc.

207 E. Ohio St., Chicago, Ill.

Iist of inspected gas, oil, and miscellaneous appliances. Free

\section{IEATING, VENTLATING, AND AIR CONDITIONING}

DEPARTMENT OF AGRICUTLURE.

Washington, D. C.

Heating the farm home (Farmers' Bulletin No 1698)...... 5 cents

Oil burners for home heating (Circular No. 406).........5. .

A study of the oil burner as applied to domestic

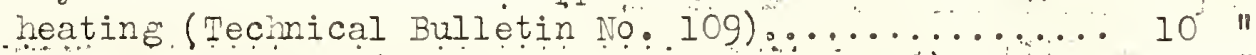

Wood fuel in wartime (Farmersi Bulietin $\mathrm{d}^{\circ}$. 1912)....... 10 "

DEPRTMENT OF COMNERCE (INational Bureau of Städäas)

Tashington, D. C.

List of publications and articles relating to home heating

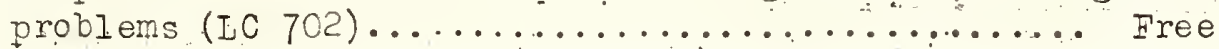

Air infiltration through windows $(B M S-45) \ldots \ldots \ldots \ldots$ cents

Effect of scot on the ratirg of an oil-fired heating

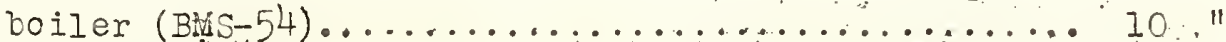

A survey of humidities in residences $(3 \mathrm{~W}-56) \ldots \ldots \ldots \ldots . . .10$

Moisture condensaticn in building walls (BNS-63) ...... 10 "

solar heating of various surfaees $($ BMS-64) .......... 10 "

Accurulation of moisture in walls of frame construction

during winter exposure $($ BNS-93).............. 10 "

Iomestic heating and air conditioning ( LC 649)........... Free

Thermostat setting and economy. in house heating ( IC 711). "

Domestic burner so for Fennsyl vania anthraci te

(Underfeed tipe) (eS.48-40).

Automatic mechanical-draft oil burners designed for

domestic installations $(\operatorname{cs} 75-42) \ldots \ldots \ldots \ldots \ldots \ldots \ldots \ldots \ldots \ldots \ldots \ldots \ldots$

Gas floor furnaces; gravity circulating type (c.5 99-42) * . . .

Flue-connected oil-burning space heaters equipped with

vaporizing. pot-type burners (CS 101-43)

Warm-air furnaces equipped with vaporizing pot-type eil burners. (C. (

solid-fuel-burning forced-air furnaces (CS 109-44)

(Mimeographed)

oil-burning floor furnaces equipped with vaprizing pottipe burners (CS 113-44)

Notes on domestic fuel oil conservation. ( $\mathrm{IC}-738$ )

$10 " 11$

10 if

Free

10 cents

Free 
DEPARTNENT OF THE INTERIOR: (Bureau of Mines)

Washington, D. C.

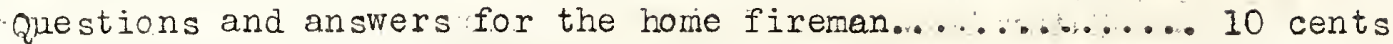

.... Questions and answers for the coal fiman............. 10 "

How: to save fuel at home (Information Circular 7229)...... Free

FEDERAL HOUSING ADMINI STRATION

Wa.shington., D.. C. .

.... Wechanical equipment for the home

(Technical Bulletin No. 6)................. 5 cents

TENNESSRE VAILEY. AUTHORITY (Information Office)

Knoxvilie, Tenn.

Studies in the heating of small houses.............. 50 cents

Bureau of Mines

Mines and Geology Branch

Department of Mines and Kesources

Ottawa, Canadá

Comparative tests of various fuels when burned in a domestic hot-water boiler (No. 705)............20 cents

Same title (No. 802 - 1935 to 1938)..................25 "

American Gas Association

420 Lexingtion Ave., New York, N. Y.

Comfort heating........................... \$2.00

- Gas and electricity for domestic cooking and heating

purposes.............................. Free

American Society of Heating and Ventilating Engineers

5 I Madison Avé, New York, IN. Y.

......Heating; vantilating, air conditioning guide (annual).... \$5.00

Better Hories in America

Purdue Research. Foundation, West Lafayette, Ind.

..... Why conditioned air in houses improves human comfort

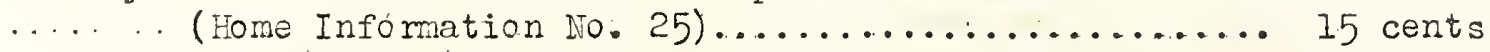

How aj. in houses is conditioned by modern equipment

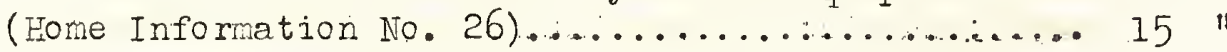

Heating, Piping, and Air Conditioning Contractors National Assn. 1250 Sixth Ave, New York, N. Y.

Ensineering standards............................ \$5.00

Net.load.racommendations for heating boilers............ 1.50

National. Tarm. Air. Heating and Air. Conditicning Association

145 Publie" Square; Cleveland, Ohio

- Standard gravity code (for instaliaticn of gravity viarm-

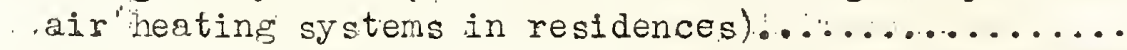

Fractical code (for installation of mechanical warm-air

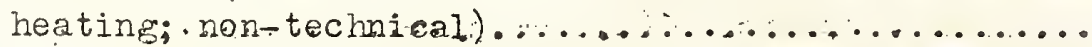

Technical code for installation of mechantcal warmair

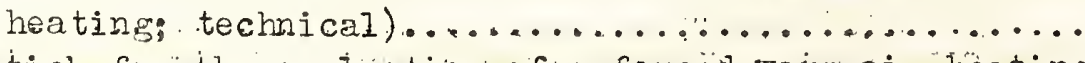

Yardstick for the evaluation of a forcëd warm-air heating

$\ldots \ldots \ldots$ system $4 \ldots \ldots, \ldots, \ldots \ldots \ldots \ldots \ldots \ldots \ldots \ldots \ldots \ldots \ldots \ldots$ 
Underwriters' Iaboratories, Inc.

207 E. Ohio 3t.", "Chicágo", IIl.

Iist of inspected gas, oil, and miscellaneous

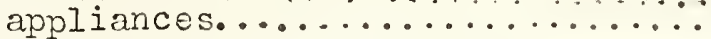

Free

$\frac{\text { HÓLIOW BUILDING TILE }}{\text { (Structural clay tile) }}$

DEPARTMENT OF COMMERCE (National Bureau of Standards)

Tashington, D. C.

Hollow building tile (RI2) (Mimeographeal)............. Free

Recommended mininum requirements for small-dwelling

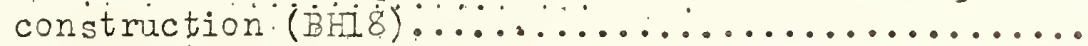

Compressive and transverse strength of hollow-tile walls

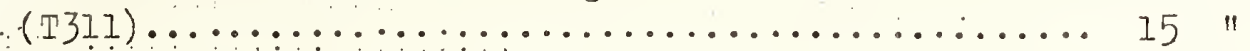

Compressive strength of structural tile masoniry (RP972).. 10 "

Tater permeability of masonry walls (BMS-7)............ 10 "

Structural clay products, stone, and masonry (IC 643).... Free

Structural clay Products Institute

1756 K St., N. W., Washington, D. C.

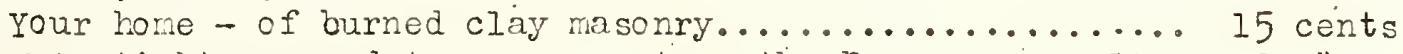

Watertightness and transverse strength of nasonry walls.. 10 "

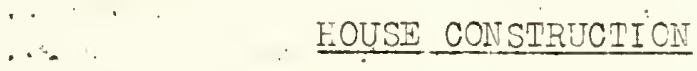

DEPARTMEIT OF AGGRTCUTURE

Washington, D. C.

Ramned-earth walls for buildings (Farmers'Bulletin No.1500) 5 cents

Foundations for farm buildings (Farners Bulletin No.1869) 10 "

DEPARTMENT" OF" AGRICUTTURE (Forest "Service)

Washington, D. C.

Use and abuse of wood in house construction

(Miscellaneous Fublicaticn No. 358).

10 cents

DEPARTMENT OF CONMARCZ (National Bureau of Standards)

Tashington, D. C.

Recommended buildin co de requiremerts for new dwelling

constriction with special 'reference to

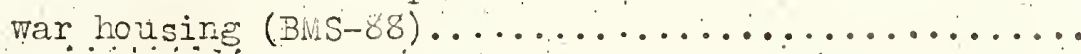

A method for developing specifications for building

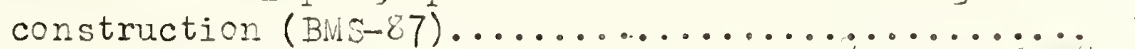

Recomended minimum requirersents for snall-dwelling

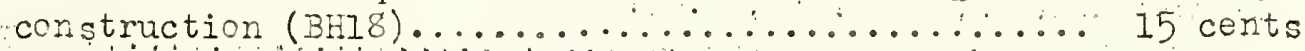

Recomended minimur requirements for pluribing (BHI3) $\therefore .50$ "

Recomended minimum requirements for fire resistance in

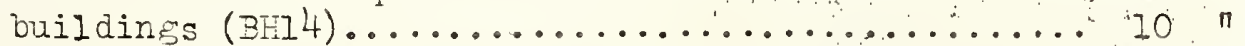

Structural properties of conventional wod-frame constructions

for walls, partitions, flocrs, and rocfs (BNS-25)... 15 cents

Experimental dry-wall construction with fiber

insulating board (BMS-97)................ 10 "

Exterior waterproofing for masonry (TIBM-5).......... Free

Masonry wall resistance to rain penetration (IIBM-58)...." " 
Dampness in masonry walls a bove grade ( IC 721) ......... Free

Field inspectors' check list for building

constmaction $(B N S-81)$.

20 cents

DEPARTMENT OF COMMERCE (Bureau of Foreign and Domestic Commerce)

Washington, D. C.

Light frame house construction (Bulletin No. 145)...... 40 cents

FEDERAI HOUSING ADNINISTRATION

Tashington, D. C.

Contract documents fór small house construction

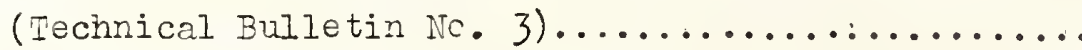

Minimum constructicn requirenents for new dwellings:

by states. (Obtainable from FHA insuring office

in each state $\ldots \ldots \ldots \ldots \ldots \ldots \ldots \ldots \ldots \ldots$ Free

DEPARTMENT OF THE' INTERIOR (Office of Indian Affairs)

Chilccco Indian School, Chilocco, Oklahoma

Earth Brick Constructicn.................... 50 cents

American Institute of Steel construction, Inc.

200 Madison. Ave.', Nev' 'Ycrk, 'N: Y.

Building to resist hurricanes in the vest Indies......... Free

Requirements for buildings to resist earthquakes........."

Light-gage flat-rclled steel in housing.............."

Manual of steel constructicn..................... \$2.00

Better Homes in America

Purdue Research. Foundation, West Lafayette, Ind.

Description and cost analysis of a steel house

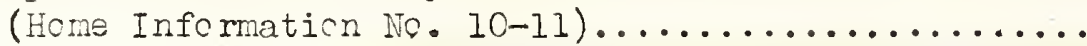

15 cents

Description and cost analysis of a wood-frame and

stucce house (Hone Information No. 14-15).......... 15 "

Description and cost analysis of an ali-wood house

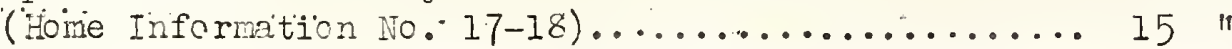

Description of a prefabricated house

(Hone Information No. 19-20).................... 15:

A low-cast house built at Indianapolis, Ind.

(Home Information INo. $21-22) \ldots \ldots \ldots \ldots \ldots \ldots \ldots \ldots \ldots \ldots$

Descripticn and cóst analysis of a reinforced

concréte house (Home Information No. 23-24) ..........

Copper and Bràs śléseàrch Association

420 Lexington Ave., New York, N. Y.

Your horne...................: : ................. Free

Dcuglas Fir Plywood Association

Tacoma Bldj., Tacona, Wash.

Construction. manuál for Douglas fir plywood heuses....... Free 
Gypsum Association

$2 I 1$ W. Wacker Drive, Chicago, III.

Gypsum sheathing........................... Free

Metal Lath Manufacturer's Association

208 s. Iasalle st., Chicaso, III.

The Iurie steel house....................... 5 cents

National. Fire. Protection. Associaticn

60 Batterymarch st., Bo.s.ton,. Mas.s.

Private residences; specifications for.............. 15 cents

National Iumber Manufacturers Association

1319-ioth .St., N. W. Wasinington, D. C.

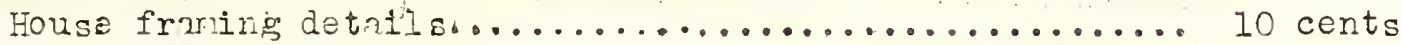

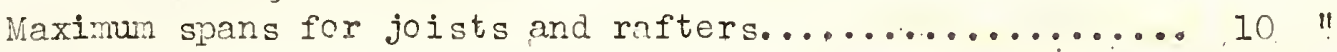

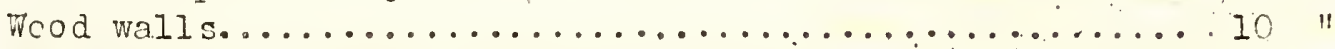

Plank ard bean flecr and $\operatorname{recf}$ syster.................... Free

Portland Gement Assciaticn.

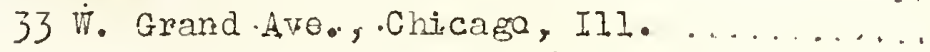

Foundaticn walls and basenents of concrete............ Free

Southern Pine Associaticn

Canal Bldg., New Orleans, Ia.

Fifteen cardinal points of correct frame construction.... Free.

Structural clay Products Institute

1756 K St.; N.T., Washington., D. C.

Manual.of.good building practices (Nimeographed)......... Free

\section{FOUSE MAINTENAICE AND NODERNI ZAIION}

DEPARTVENT. OF. AGRI CULTURE

Washington, D. C.

Mo dernizing farmouses. (Gamers'Bulletin lio.1749)...... 10 cents

DEPARTUENT OF COMUEC (Naticnal Buraau of Standards).

Tashingtcn., D. .C..

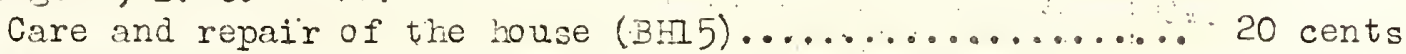

Check list $\rightarrow$ Suggestions for possible repairs and

imprcveinents in the house and its equipment........ Free

American Gas Assciaticn

420 Lexington Avo., New York, N. Y.

Profitabje modernization by use of gas................ Free

Metal Iath Manufacturers Association

$208 \mathrm{~s}$. Ia Salle St., Chicago, Ili.

Conerete stucco for modernizing................... Free 
Plumbing and Heating Industries Bureau

35 E. Wacker. Drive, Chicago,. Ill.

Modernization of bathroom plumbing.

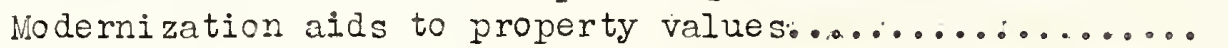

Free

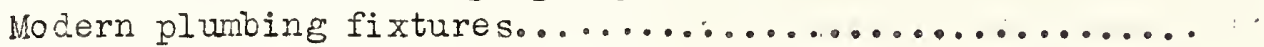

Fortland Cement Association

33 W. Grand Ave., Chicago, IIl.

Concrete improvements around, the home.

Free

Western Dine. Association....

Yeon Blds., Fortland, Oreg.

Paneling old or new interiors with real piné.

10 cents

Beautiful paneled walls of genuine white pine.......... 10 "

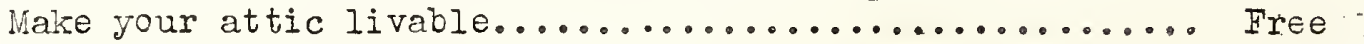

Bunk bedroom details...

\section{HOUSEHOLD HELPS}

DEPARTMENT, OF AGRICUT,TUKE

Tashington, D. C.

Methods and equipment for home laundering

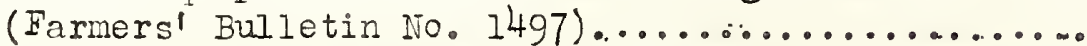

Window curtyaining (Farmers' Bulletin No: 1633) ..........

Closets and storage spaces (Farmers' Bulletin No.1865)...

5 cents

5 "

5 "11

DEPARTIENT OF COMMERCE (National Bureau of Standards).

Washington, D. C.

Washing, cleaning, and polishing materials (c424)........

Fublications relating to accident prevention and.

15 cents

. safety (IC 60$) \ldots \ldots \ldots \ldots \ldots \ldots \ldots \ldots \ldots \ldots \ldots$ Free

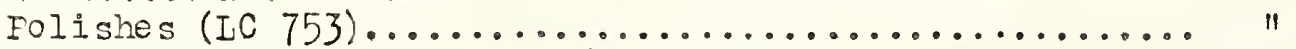

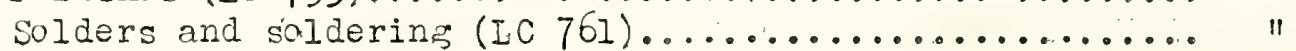

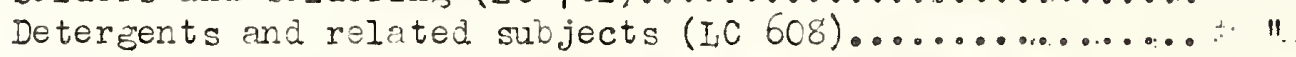

Publications of interest to the general public

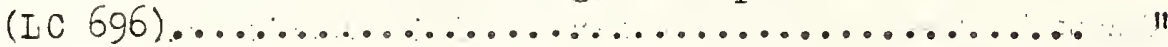

DEPARTIENT OF COMMERE (Bureau of Foreign and Domestic Commerce)

Vasington, D. C.

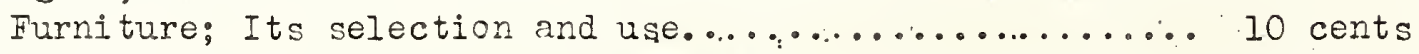

FIDERAI SECURITY AGENCY (Public Heal th Service)

Tashington, D. C.

Until the doctcr comes (Fublic Health Service).

Miscellaneous Publicaticn No. 21; 1941 edition)...... I5 cents 
Better Homes in America

Purdue Research Foundation, West Iafayette, Ind:

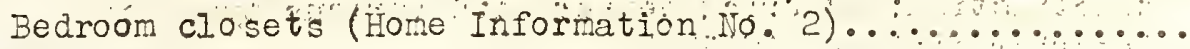

curtains;." their selection' and ho"w to make thëm

(Home Information No 3) ....................... I5 "

Walls and wall treatments (Home Information No.8)...... 15 "

Underwriters Iaboratóries, Inc.

207 E. Orio St., Chicago, III.

List of inspected electrical

1 equipment.

Free

National Lime Association

927 Fifteenth "St."; N. W.; Washington, D.C.

Lime hints for the home.

Frree

\section{INSULATION AND" SOINDPPOOOEING}

DEPARTMENT OF COMMPRCE (National Bureau "of Standaras)

Washington, D. C.

Thermal insulation of buildings $(c 376) \ldots \ldots \ldots \ldots . . . . .$.

Aluminum foil insulation (IC 535).

5 cents

Effect of ceiling insulation upon sumer comfort

(BMS-52).

Acoustics: Publications by members of the staff of the

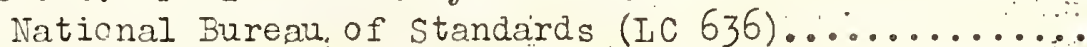

Sourid Insulation of wall and flcor constructicns

(BMS-17)

Sound Insulaticn of wall and flcor constructions

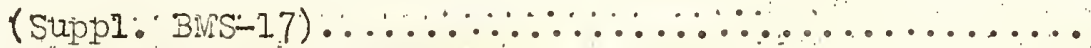

Sound absorption coefficients of the riore comon acoustic materials ( $\mathrm{C}$ C 714): :

Thermal insulation of dwelling houses (I C 759)..........

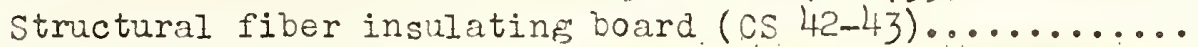

Mineral-wool; 100 se, granulated or felted form, in

low-terperature installation's (CS 105-43)........................

Thermal insulation: Comparative estimated fuel savings

- in heating 'dweling" hou'se's" équipped" with" various

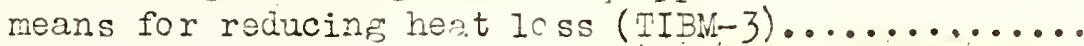

Free

10 cents

Firee

10 cents

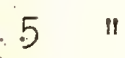

Free

"

5 cents

511

Free

Thermal insulation: Insulating values of thermal insulating materials, building máterials, and basic

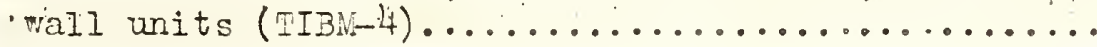

"

Thermal insulation: Comparative insulating values of 8" solid brick walls having various types of interior

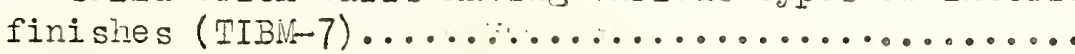

Thermal insulaticn: Insulating values for frame. wall constructicn; wcod siding with varicus typos if.

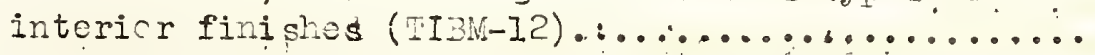

Therma insulaticn: I-sulating values for.frame vall construction; stucco with various types of interior finishes (TIBM-13). 
Thermal insulation: Insulating values for frame wall construction'; "L"l 'brick veneer wi-th various types of

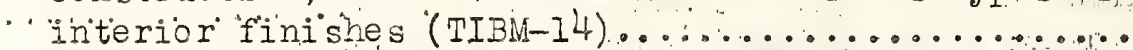

Thermal insulation: Insulating values for frame wall 'construction; woo' shingles with varicus types of

"Interior finishes (TIBM-15)...

Thermal insulation: Sumary and conclusions (TIBM-i6).

DEPARTMENT OF THE INTERIOR (Bureau of Mines)

Washington: " D: 'C:

Home insulation with mineral products

(Information Circular 7220$) \ldots \ldots \ldots \ldots \ldots \ldots \ldots \ldots$ Free

Acousticál Mátèriàls Assỏciatión

Palmolive Blds., Chicago, III.

Theory and use of architectural acoustical materials; sound absorption coefficients;" sound"linsuläticn

(Bulletin No. VIII)

Free

Better Homes in America

Purdue Kesearch 'Foundatión; west Lafayette, Ind.

Thermal insulation of houses (Home Information No.4) ..... is cents

Insulation Board Instituté

111 W. Washington St., chicaso," III.

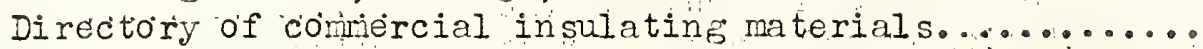

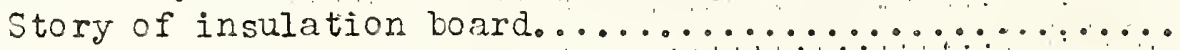

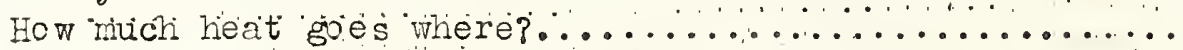

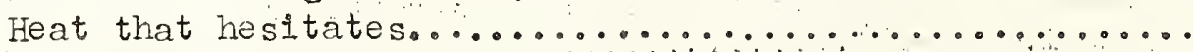

Dininishing effectiveness cic sucessive thicknesses of

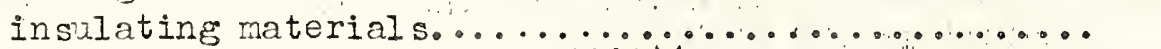

Application instructions for structural insulating board. n

Metal Iatr Manufactirers Association

208 S. Iasalle St., Chicago, III.

Sound insulation properties of partitions (In Fartition

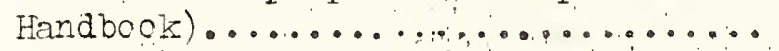

25 cents

Free

. If

H

$n$

National Mineral Tool Associaticn

1270 Sixth Ave, New York, N. Y.

Installation of mineral wcol insulation by hand methods. Free

\section{KITCHEIS}

DEPARTMENT OF ACRICULTURE

Tasington, D. C.

"Clo sets and stcrage spaces" (Farmers" Bulletin No.1865) ..... 5 cents

DEPARTMENT OF COMMERCE (National Bureau of Standards)

Washïngton; $D_{0}$ "C:

Colors for kitchen accessories (CS 62-38)

5 cents 
FEDERAI HOUSING ADMINISTRATION

Washington, D. C.

Mechanical equiprent for the home (Tech. Bulletin No.6)..

5 cents

American Gas Associaticn

420 Lexington Ave., iNew York, iN."Y.

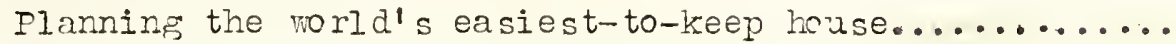

Free

Modern kitchens and basements................... \$1.35

Steel Kitchen Cábinet Institute

1621 Euclid Ave:, Clevelard, Ohio

Quality standards for steel kitchen cabirets........... Free

Underwriters' Iaboratories, Inc.

207 E. Ohio st., Chicago, III.

Iist of inspected electrical equipment.............. Free

Western Pinè Association

Yeon BIdg., Portland, Oreg.

Ten ídeas for modern kitchens.................. Free

\section{IANDSCAPING}

DEPARTMENT OF AGRICULTURE

Washington, D. C.

Beautifying the farmstead. (Farmers! Bulletin No.1087) $\therefore$. 5. cents

Planting and càre of lawn's (tarmers' Bulletin 10.1677) ... 5. "

FEDERAI SECURITY AGENCY (U. S. Office of Education)

Washington, D. C.

Iand scaping the famisted ' (Bulletin No. 189)

15 cents

Californià Rediód Association

405 Montgonèry. St.; Sän Francisco; Cảilf:

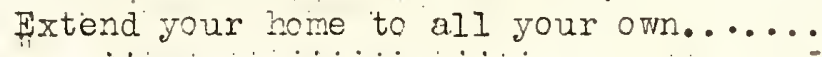

Free

National Iimé Aśscciation

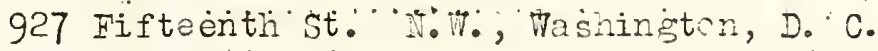

Iime on latins and flcver fardens (Bulletin $180-A) \ldots . .$. Free

Southern Finè Associaticn

Canal Bldg.; New Orlèis, Ia.

Beautifying the home grounds (A plan book)........... 25 cents

\section{$\ldots \ldots \ldots$}

DEPARTAENT OF CONARCE (Naticnai Bureau of Standaras)

Washingtori; 'D. C.'

A study of the properties of mortars and bricles and their relation tc bond ( $\mathrm{RP} 683$ ).

Nortar and brick properties and their relation to bond

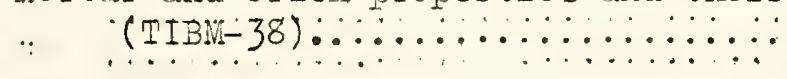

5 cents (TIBN-38) $\ldots$ 
Naticnal Iine Association

927 Fifteenth St. N.W., Washington, D. C.

Iime nortar - Its relation to watertight masonry

(3ulletin 320).

Free

\section{PAINTING AND DECORATING}

DEPARTMENT OF AGRICULTURE

Wa shington, D. C.

Painting on the farm (Farmers' Bulletin No.1452)........ 5 cents

Why some wood surfaces hold paint longer than others

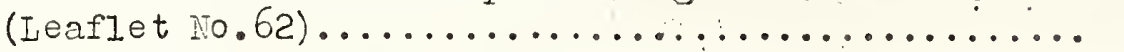

511

DEPARTIENT OF AGRICUITUEE (Forest Products Laboratory)

Madison, Wis.

Painting exterior woodwork (Mimeo graph Rio29)..........

Behavior of house paint.s on different woods

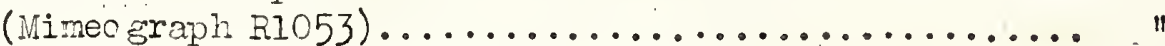

When and how to paint homes and farm buildings

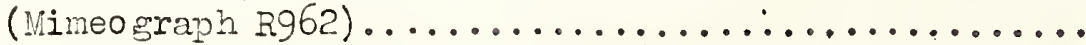

Repainting, the paint-neglected rouse (Mimeograph Rl135)..

Some causes of blistering and peeling of paint on house

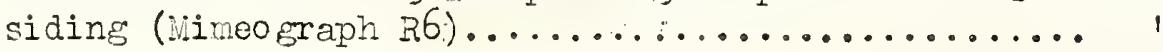

DEPARTMENT OF COMNERCE (National Bureau of Standards)

Washington, D. C.

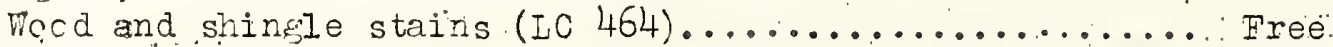

Painting of steam and hot-water radiators (IC 445)......"

Paint, varnish, and bituminous materials (IC 659)....... n

Sources of information on paint and related

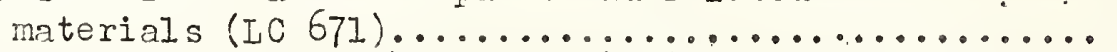

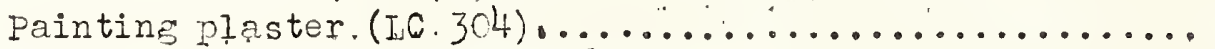

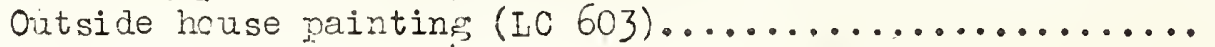

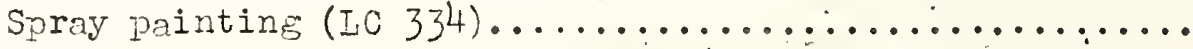

The painting of structural matal (steel, galvanized metal,

tin plate, and copper) (. 40.422$) \ldots \ldots \ldots \ldots \ldots \ldots$

painting steel potable vater tanks (IC 744).............

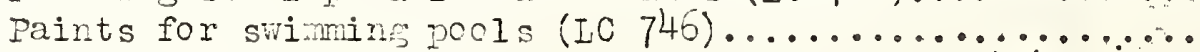

Painting, exterior walls of porous na sonry (IC 747) .......

Refinishing wood furniture $(10748) \ldots \ldots \ldots \ldots \ldots \ldots \ldots \ldots$

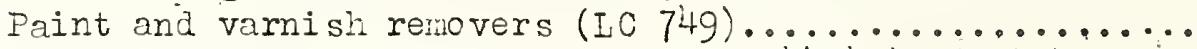

Paints, varnishes, and containers $(2144-43) \ldots \ldots \ldots \ldots \ldots$

Surface treatment of steel prior to painting "(BMS-44)...

Wal1 paper (CS 16-29).

Tests of cement-water paints and other waterproofings

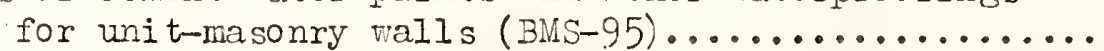

Paint for priming plaster surfases $($ TBM-11)...........

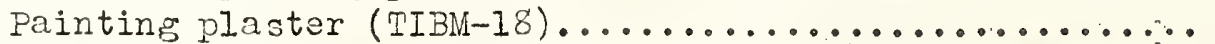

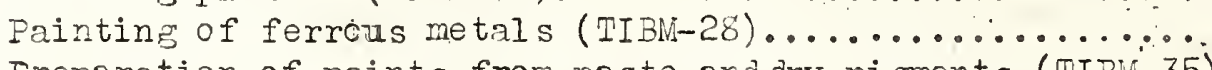

Ereparaticn of paints from paste and dry pi gments (TIBM-35)

Preparation of paints from semipaste paints, thinning

ready-nixed paints, and preparation of water

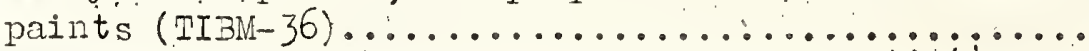

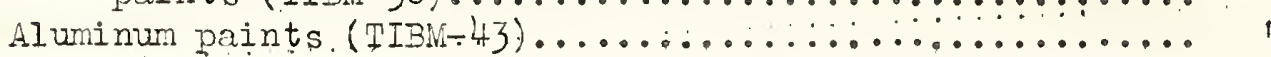




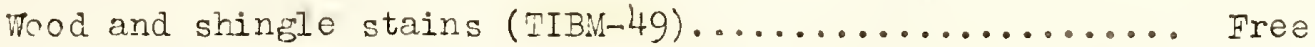

Conservation of linseed oil in paint (IC 717).........."

FEDERAL HOUSING ADMINISTRATION (Technical Division)

Washington, D. C.

Two-coat paint systems for extericr use (Circular No.6).. Free

FEDERAL SECURITY AGEICY (U. S. Office of Educaticn)

Washington; D. C...

Training for the painting and decorating trade (Bulletin No.193)

35 cents

American Zinc Institute, Inc.

60 E. 42nd St., New York, N. Y.

Wetallic zinc paint............................. Free

The Paint Industry Masazine

901 Cunard BldF., Philadelphia, Pa.

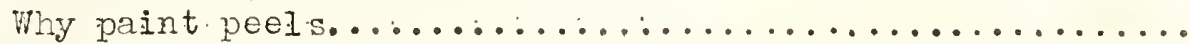

25 cents

The new paint, varnish and lacquer catechism:

Complate............................... 50

Paint section........................... 25 "

..Vrrnish section......................... 25 "

Lacquer section......................... 25 "

Painting and Decorating Contractors of America

828 Jefferson BIds., Peoria, Ill.

painting and decorating wo rking, methods............ \$2:00

(-Theo: AudeI \& Co:; pubIIshers, :

49 W. 23rd st., New York, N. Y.)

Lead Industries Associaticn

420 : Lexington Ave.; $\mathbb{N e w}$ York; 15 . Y.

Property protection with white lead paint............. Free

Lead (bi-monthly publication) .................." "

Naticnal Iime Assciation

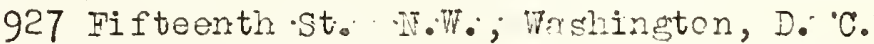

Whitewasi and cold-water paints (Bullétin 304-D)........ Free

National Paint, Vamish and Lacquer Assciation, Inc.

1500 Rho.de I-sland Ave.; Washington, D. C.

Construction defects (Circulnr No.428)............. 50 cents

Southern Cypress Manufacturers :Ascociation

Barnett Na.tienal. Bank. Bldg.; Jacksonville, Fla.

How to paint. Ti dewater red cypress. $\ldots \ldots \ldots \ldots \ldots \ldots \ldots$. Free

The Vallpaper. Institute

$19 \pi .44$ th St., New York, it. Y.

Wallpaper is the fashionable back round.............. Free

West Coast Iumbermen's Assciaticn.

364 Stuart.BId5., Seattie, Tash.

Painting and finishing Test Ceast woods.............. Free 
DEPARTNENT OF AGRICULTURE

Washington, D. C.

Farmhouse plans (Farmers' Bulletin No.1738)........... 10 cents

Plans of farm buildings for Western states

- (Miscellaneous Fiblication No.319).............6 60 "

Flans of farm buildings for scutrern states

(Miscellanecús Fublicaticn No.360).

60.11

DEPARTMENT OF AGRICUITURE (Farm Security Administraticn)

Washingtón, D. C.

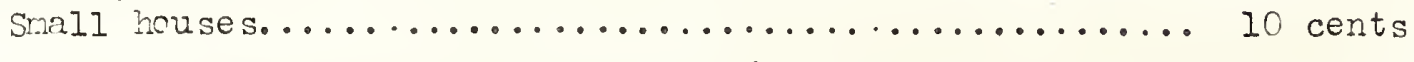

DEPARTMENT OF COMMERCE (Naticnal Bureau of Standards)

Mashingtori, 'D: C.

House plan services (IC 428).

Free

FEDERAL HOUSING ADMINISTRATION

Vashingtion, D. C.

Modern design (Techínical Bulletin No.2)...

.5 cents

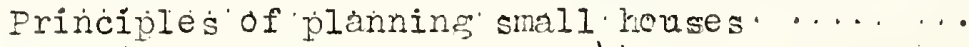

(Téchícal Bulletin lic:4): : .

10."

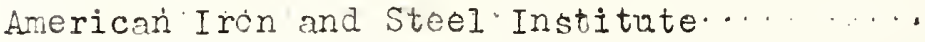

350 Fifth Ave., New Ycrk, N. Y.

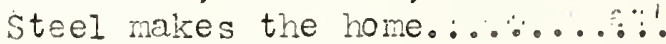

Free

Californià'Rearood'Associaticn

405 Monteromery St, San Francisco, Calif.

styling your home........................... Free

Deuglas fir Plywood Associaticn

Tacoma B? ds., Tacomä, Wash.

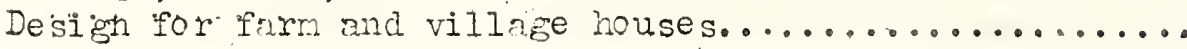

Frea

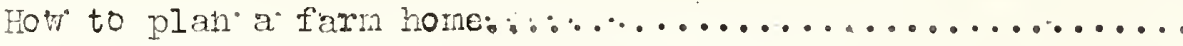

National Concrete Masonry Assciaticn

33 \%. Grand Ave., Chicago, Ill.

Twenty-elght concrete homes by leading architects.......

Free

Naticnal Iumber Nanufacturers Assciaticn

1319-18th St. N. W. , Washingten, D. C.

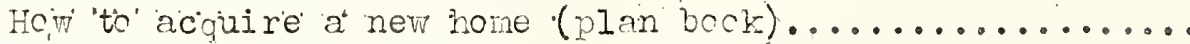

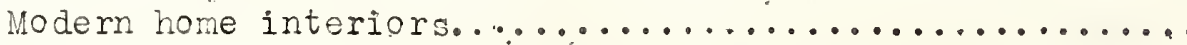

The best way to achieve low-cost housing is

to build lcw-cost honies (plan bcok)............ 10 "

Portland Cement Asscciation

33 W. Grand Ave., Chicago, 111.

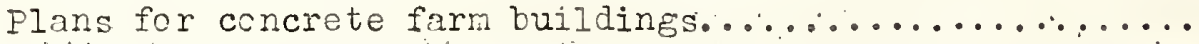

Súfgestéd de signs for small firesafe concrete houses.....

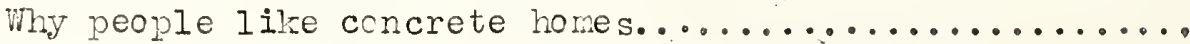

10 cents

10 "

Free

$"$

"1 
Red Cedar Shingle Bureau

5508 Thite B́lds: Seattle, Tash...

A portfolio of certigrade homes.

10 cents

Southern Pine Association

Canal Bldg., Nev Orleans, La.

Iivable homes of scuthern pine (plan book). $\ldots \ldots \ldots \ldots \ldots$

Low-cost homes and summer cottages (plan book ) . . . . . . . .

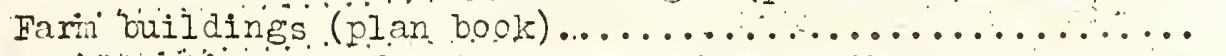

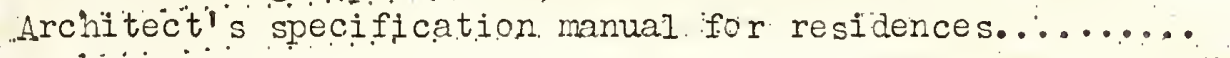

25 cents

15 "

15 "

Free

\section{PIASTER AND STUCCO}

DEPARTIENT OF AGRICLITURE (Bureau of Plant Industry, Scils, and Ta shington, D. C. .Aricultural Engineering)

Plaster and plastéring (Information Series No.32)....... Free

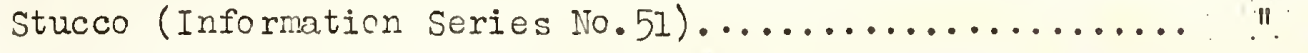

DEPARTMENT OF COMMERCE (Naticnal Bureau of Standards)

Wa shington, 'D." 'C."

Wall plaster - Its ingredients, preparaticn, and properties

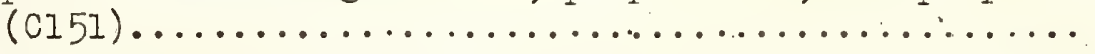

Gypsun: Publicaticns by the staff of the Naticnal Bureau

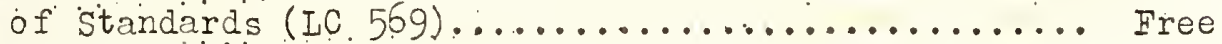

Metal' lati' (expanded and sheet) and metal plastering

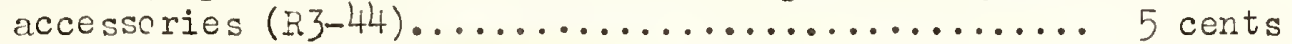

Suitability of fiber insulation lath as a plaster

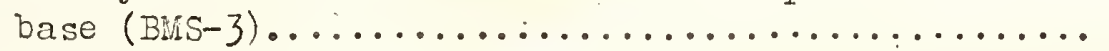

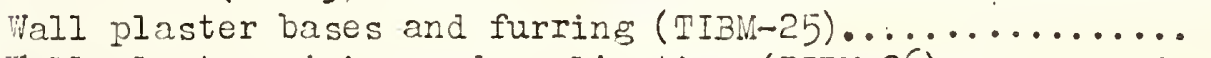

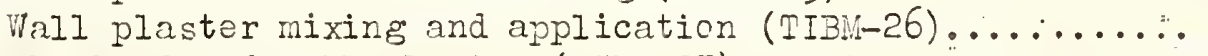

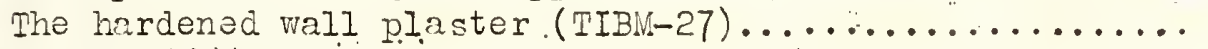

Investigaticns of portland cement stucco construction

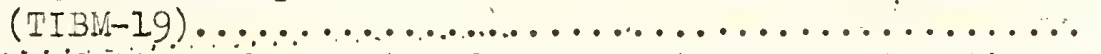

$15^{\prime}$ cents

$10 " 11$

Free

II:

"'

II

Reconinendaticns for portland cement stucco construction $($ TIBM-20)

Finishes and maintenance of pertland cement stucco" construction $(\mathrm{TIBM}-21) \ldots \ldots \ldots \ldots \ldots \ldots \ldots \ldots \ldots \ldots \ldots \ldots \ldots \ldots \ldots \ldots \ldots$

II

Tater permeability and weathering resistance of stucco-faced, gunite-faced, and. "Knap concrete-unit" wàlls $(B N \dot{S}-94):$ a $_{1} \ldots \ldots \ldots \ldots \ldots \ldots \ldots \ldots \ldots \ldots$

10 cents

Better Homes in Arierica

Purdue Keseiarch" Ficüdation, "7e st. Lafayette, Ind.

Plaster cracks in houses; their cause, preventicn, and cure

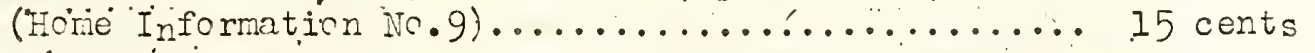

Gypsum Asscciation

211 W. Wacker Drive, Chicago, Ill.

Brief cn gypsum plaster......................... Free

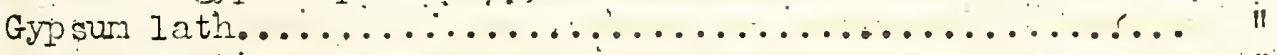

Gypsum board............................... "

Gypsum - à ncnmetallic mineral................. "

Standard specifications for gyp sum plastering..........." 
Adheston of gypsum plaster to varicus backings......... Free

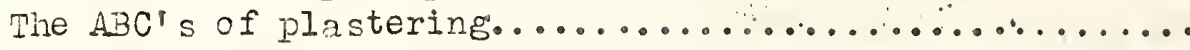

Metal Iath Manufacturers Assciaticn

208 S. IaSalle St., Chicago, IIl.

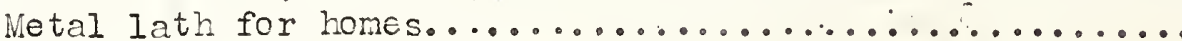

Metal Lath. News:

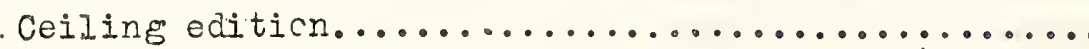

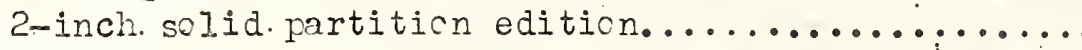

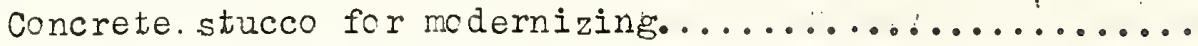

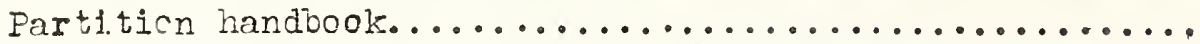

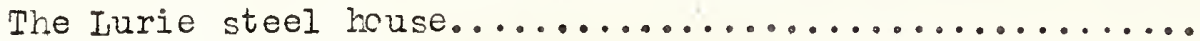

Standard metal lath specificaticns for better plastering

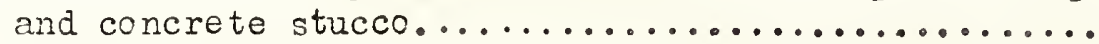

Proper constructicn details for attaching metal lath to

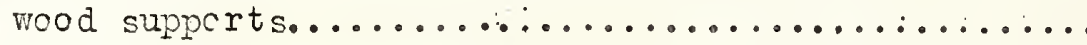

Free

10 cents

10 "

Free

$\$ 1.00$

5 cents

5 II

Free

Naticnal. Iime. Association.

927 Fifteenth St. .N. W. Washington, D.C.

Specificaticns for lime plaster and lime stucco.........

Free

Portland. Cement Associaticn

33 W. Grand Ave., Chicago, III.

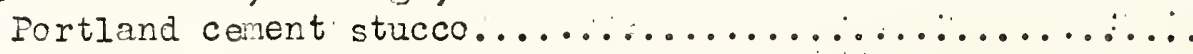

Plastarer's manual.

Free

11

\section{PLUNBING}

DEPARTMENT OF .AGRICULTURE

Washington, D. .C. .

Farm plunbing (Farmers' Bulletin No.1426).

Simple plumbing repairs in the home

.. (Earmers' Bulletin No.1460).

10 cents

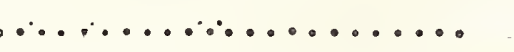

5 "

DEPARTMENT OF COMMERE (Naticnal Bureau of Standards)

Tashinston, D. C.

Hecommended minimu, requirenents for plumbins (BHI3).... Methods of estinating loads in plumbing systems (BMS-65). PIưmbing manual (3MS-66).

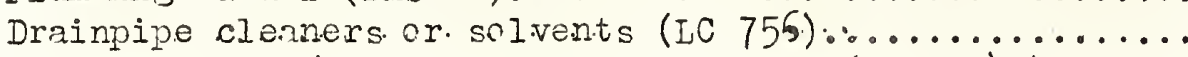

Staple vitreous china plumbing fixtures (CS 20-42)......

Staple seats for water-clo set bowls (Cs 29-3i)..........

colcrs for sanitary ware $(\mathrm{Cs} 30-31) \ldots \ldots \ldots \ldots \ldots \ldots . . . \ldots$

CcIcrs for. bathrom accessories (cs: $63-38) \ldots \ldots \ldots \ldots \ldots \ldots$

Sanitary. cast iren. enameled. ware (cS 77-40)............

Earthenware (vitreous-glazed) plumbing fixtures

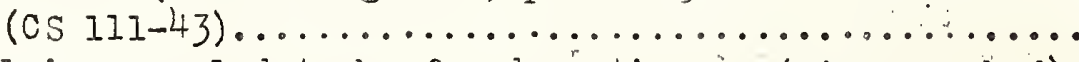

Porcelain-enameled tanks for domestic use (Mineographed)

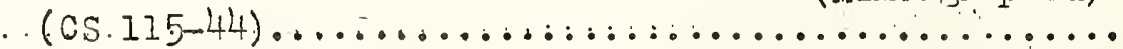

Bituminized-fiber. drain and. sewer pipe (CS.116-44) .......

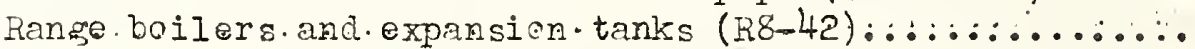

50 cents

10 II

20 it

Free

10 cents

$\begin{array}{rl}5 & \text { " } \\ 20 & \text { " } \\ 5 & " 1 \\ 5 & \prime \prime\end{array}$

$5 \quad 11$

Free

5 cents 
FEDERAI HOUSING ADMINISTRATION

Washington, D. C.

Mechanical equipment for the home. (Tech. Bulletin No.6).. 5 cents

TENNESSEE VALIEY, AUTHOKITY. (Information Office)

Knoxvilié, Tenn.

Pump and plumbing for the farmstead................ 50 "

Lead Industries Association

420 Lexington Ave., New York, N, Y.

New simplified standard for lead traps and bends........ Free

Iead (bi-monthly publication)..................."

National Association of Master Plumbers of the United States, Inc.

917 Fifteenth St. N. W., Washington, D. C.

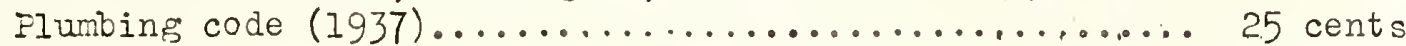

Report on plumbing cross-connections and back siphonase

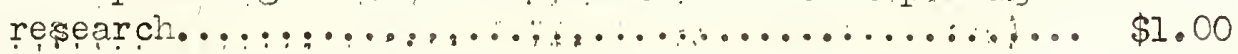

Report on hydraulics and pneunatics of the plumbing

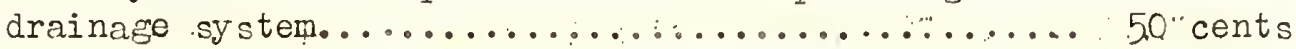

Pacific Coast Plumbing Inspectors Association

4733 Templeton St. , Ios Angeles, Calif:

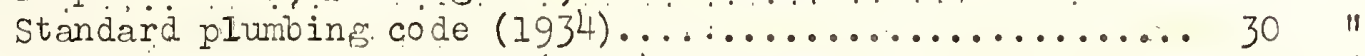

Standard water pipe code $(1939) \ldots \ldots \ldots \ldots \ldots \ldots \ldots \ldots \ldots \ldots \ldots$. 25

Rlumbing and Heating Industrị șurẹ

35 ir. Wackér Drive, Chicago, Iil.

"The importance of correct piping design and installation. Free

Sanitary Cast Iron Enameled Tare Asşociation

1108 Clark' 'Bidg, pittsbur, sa.

The handing and care of enameled cast iron plumbing

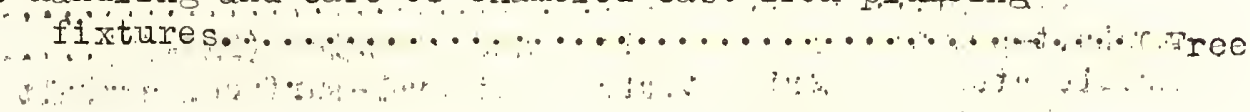

$\ldots \ldots \ldots$ PORCEIAIN ENAMEI PRODUCTS

DEPARTMENT' OH' COMMERCE (National Bureau of standards).

Washingtion, D.

Porcelain-enameled tanks for domestic use (CS 115-44)

(Mineo sraphed).

Free

Porcelain Enamel Institute, Inc.

612 N. Michigan Ave Chicago III.

Recommended materials and practice for architectural

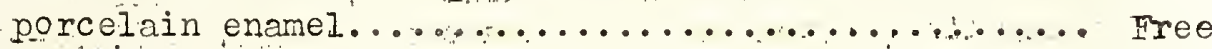


DEPARTNENT OF COMMER (National Bureau of Standards)

Washington, D. C.

Domestic electric and bas refrigerators (IC 472)....... Free

Heating; Piping; and Air Conditioning Contractors National As sociation

1250 Sixth Ave., New York, N. Y.

Mechanical refrigeration.

50 cents

\section{ROOFING}

DEPARTMENT OF AGRICUITURE

Washington; $D_{0} \cdot \mathrm{C}_{0} \ldots \ldots \ldots$

Roof coverings for farm buildings and their repair

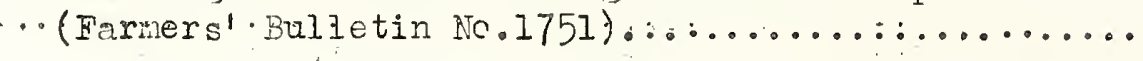

5 cents

DEPARTMENT OF CONMERCE. (National Buread of Standards)

Tashington, D. C.

Survey of roofing materials in the southeastern states

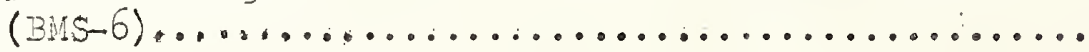
Survey of roofing materials in the Northeastern states

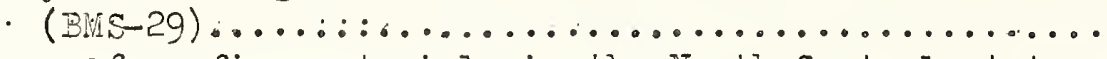

Survey of roofing materials in the North Central states

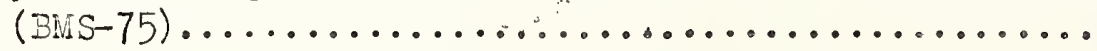

Survey of roofing materials in the South Central states

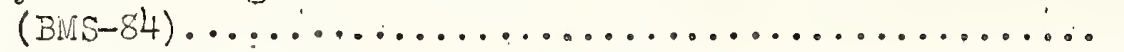

Metallic roofing for low-cost house construction

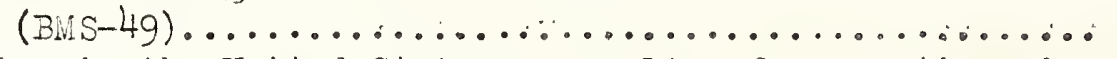

Rcofing in the United States - results of a questionnaire

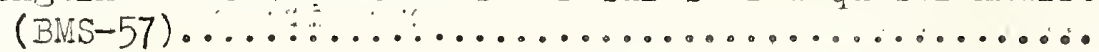

Asphal twprepared roll roofings and shingles (BMS-70)....

Accelerated weathering tests of mineral-surfaced asphalt

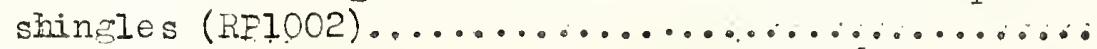

Paint, varnish, and bituminous materials (IC 659) ........

Eaves trough and conductor pipe $(\mathrm{R} 2 \mathrm{~g}-42) \ldots \ldots \ldots \ldots \ldots$

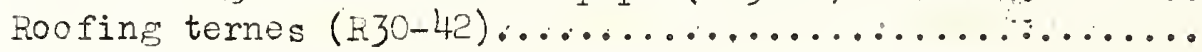

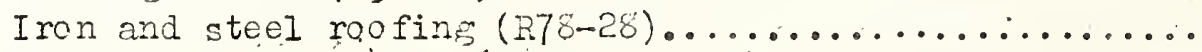

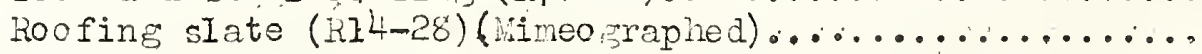

Recomended minimun' requirenents for small dwelling

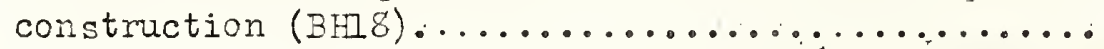

Types of decks adapted to bituminous built-up roofing

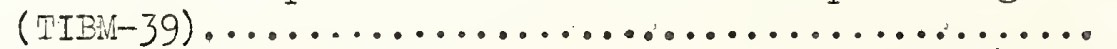

Naterials used in bituminous built-up roofing (TIBM-40)..

Roofing tin (galvanized) for house construction (TIBM-4I)

"Black" and galvanized sheets for use in house

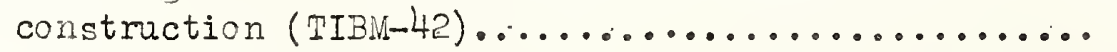

Shingles: mineral-surfaced asphalt (TIBM-5l)..........

Wood shingles (Red cedar, tidewater red cypress,

California redwood) (CS $31-38) \ldots \ldots \ldots \ldots \ldots \ldots$

15 cents

1011

$15 \mathrm{n}$

15 "

$10 \% \pi$

$10 \mathrm{HI}$

$15 \mathrm{n}$

10 "

Free

5 cents

$5 \pi$

$5 \pi$

Iree

15 cents

Free

H

II

II

$\|$

5 cents 
NAVY DEFARTMENT (Bureau of Yards and Docks')

Washington, D. C.

Specifications for roofing, siding, and sheet-metal work;

đámpprcofing and membrane waterprocfing (No.7Yg) ...

Free

American 7inc Institute, Inc.

60 E. 42nd St., New York, N. Y.

Directions for laying galvanized roofing............ Free

Facts about galvanized sheets.........................

Copper and Brass Research Association

420 Lexington Ave., New York, N. Y.

Your home................................ Free

Flashinss, gutters and downspouts................ "

The life of your rof hangs by a nail................ II

Iead Industries Assciaticn

420 Iexineston Ave., Nev York, iN. $\mathrm{Y}:$.

Lead (bi-monthly publication).................. Free

National Association of Flat kolled Steel Manufacturers

Oliver Bldg., Pittsburgh, Pa.

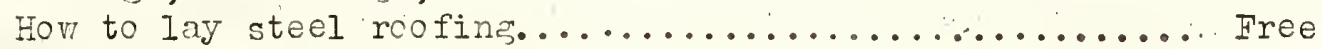

Galvainzed roofing - its use and application.........." "

Hov to ground a salvanized roof against lightning ......"

National Slate Assciation

325 E. 57 th st., New Yorix, N. Y.

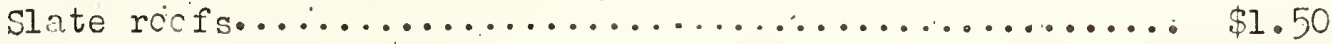

The incomparable beauty of slate rocfs............... Free

Northern Hemlock and Hardwood Manufacturers' Association

Oshkc sh, Wis.

Specification manual for use of white cedar shingles..... Frée

Red Cedar shingle Bureau

5508 White Bldg., Seattle, Wash,

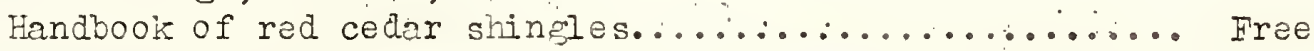

Roofs and exterior walls of red cedar shingles........... $!$

Blueprints - rèd cedat shingle application.............

SEWAGE DI SPOSAL

DEPARTMETI' OF' AGRICUTTLRE.

Washington, D. C.

Sewage and garbage di sposal on the farm

(Farmers' Bulletin Nc.1950).

10 cents

DEPAKTMENT OF COMMERE (Naticnal Bureau of Standards).

Nașingtan; $B_{0} \cdot C$.

Bituminized-fibar drain and sewer pipe (os 116-44)

5. 11 
FEDERAL SECURITY AGENCY (Fublic Heal th Service)

Washington, D. C.

Sewage di spo sal for.suburban and country homes

(supplement 58 to $\mathrm{P}_{\text {. }} \mathrm{H}_{0}$ reports) ..

Free

Sani fary privy (Supplement $10 E$ to P. Ho reports)........." "

FEDERAI, HOUSING ADMINISTRATION

Washington, D. C.

Mechanical equipment for the home.

(Technical Bulletin No.6)................ 5 cents

Better Homes in Ame rica

Furdue Research Fcundation, West Lafayette, Ind.

Safe sewage disposal for rural homes

(Home. Info rmation 1 o. .28) $\ldots \ldots \ldots \ldots \ldots \ldots \ldots \ldots, 15$ "

Eastern Clay Products Association

906 Colonial Bldg., Philadelphia, Pa.

Sewase di.spo.sal for farms and suburiban homes........... Free

Portländ Cement Assciaticn.

33 W. Grand Ave., Chicago, Ill.

Concretee s.tructures for. farm water supply and sewage

di spe sal.

Free

\section{STONE}

DEPARTIENT OF AGIICUITURE (Bureau of Plant Industry, Soils, and Washington, D.C.. . . Agricul tural Engineering)

Rubble masonry (Information Series $\mathbb{N o}$.54)............. Free

DEPARTMENT OY CONMEKCE (Naticnal Bureau of Standards)

Tashington, D...

Colors and finishes for cast stone (CS 53-35)......... 5 cents

Structural clay products, stone, and mascnry (IC 643).... Free

FEDERAI GECURITY AGENCY. (U. S. OOfice -of Educaticn) :

Washington, D.........

Stcne setting. (Builetin To.106) .....................20 cents

Indiana Iimestone Institute

Bedford, Ind:

Indiana limestone.

Preè

\section{$\therefore$ WATER}

DEPARTMENT OF AGRICULTURE

Washington, D. C.

Farmstead water supply (Farmers' Bulletin Nc.1448).....5 cents

Farm water power (Farners' Bulletin No.1658) .......... " " 
FEDERAI HOUSING ADMINISTRATION

Wasington, D. "C.

Mechanical equipment for the home (Tech.Bulletin No.6).. 5 cents

TENNESSEE VATIEY AUTHORTTY (Information Office).

Knoxville, Tenn.

Pump and plumbing for the farmstead.............. 50 cents

Better 'Fomés in' Amertca.

Purdue Fiesearch Foundaticn, West Iafayette, Ind.

Water 'supply for rural houses (Home Informaticn No.27)... 15 cents

Portland Cement Assciciaticn...

33. W. Grand Ave., Chicago, III.

concrete structures for farm water supply and sewage

di spo sal.............................. Free

\section{WOOD AND IUUNBER}

DEPARTIENT' OA'AGRICELTUTE.

Washington;" D:' C:'

The 'use' of $10 \mathrm{gs}$ and pozes in farm construction

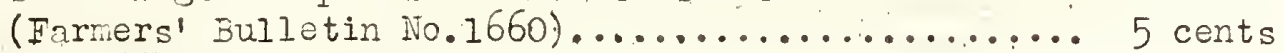

Selecticn of lumber for farm and home building

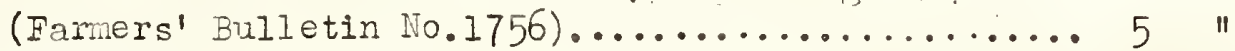

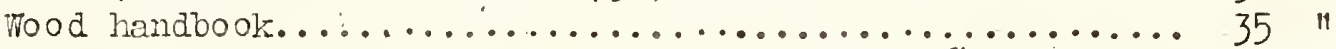

How lumber is graded (Department Circular No.64)........ 10 "

DEPARTIENT OF COMERCE (Naticnal Bureau of Standards)

Tashingtơn, D: C......

Recommencled minimum requirements for small dwelling

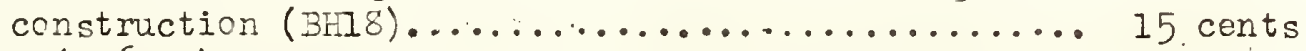

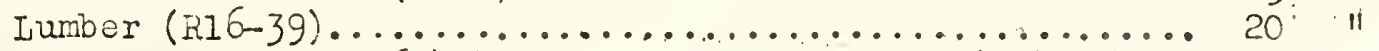

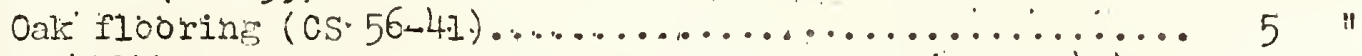

Old 'rowth Douglas fi.r. standard stock doors (CS 73-43)... 10 H

Factory-fitted Douglas fi.r entrance doors (CS 91-41).... 5 "

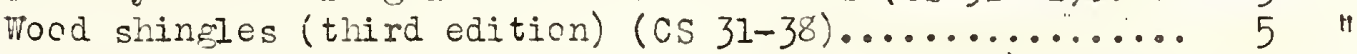

Plywood (hardwcod and eastern red cedar) (CS 35-42)..... 10."

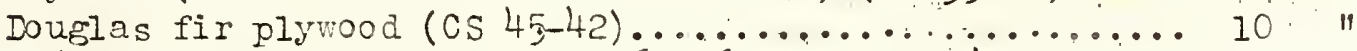

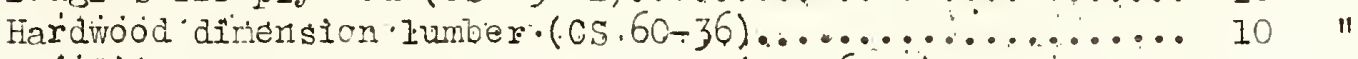

Haŕdwöod interic $r$ trim and mol ding ( CS 76-39) ......... 5 "

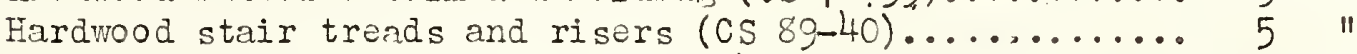

Hardwood wall panelins; solid (cs 74-39).............. 5."

Standard stcck Fondero sa pine doors (CS 120-44)

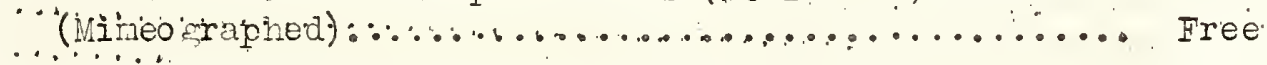


DEPARTMENT OF COMMERCE (Bureau of Foreign and Donestic. Commerce) Washington, D. C.

Amerioan Douglas fir plywood and its uses:

(Trade Fromoticn Series No.167).

California redwcod and its uses

(Trade Promotion Series No.171).

10 cents

American hardwods and theix uses
(Trade Promotion Series No.178

American hardwods and theix uses
(Irade Promotion Series No.178).

$10 \ldots$

American Western pines and their uses

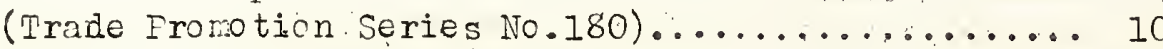

15 "

American hardwood flooring and its uses

(Trade Promotion Series No.186)................... 10 "

American southern pine

(Trade Promoticn Series No.191).................... "

American Southern cypress.

(Trade, Promotion. Series. No.194)............... 10 "

American hardwood dimension, solid wall paneling

and interior trim (Trade Promotion Series No.201)... 10 "

American hardwood plywodd

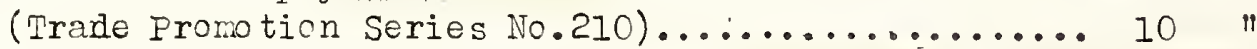

End-matched softwood lumber and its uses.............. 5 . "

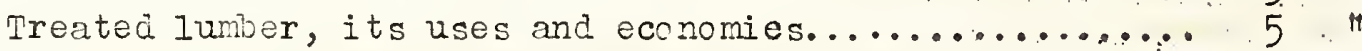

Wood constructicn ( 700 page handbook)

(McGraw. I.ill. BCok. Co., 370-7th Ave., New York, N.Y.) \$6.00

FEDERAL HOUSING ADVINISTRATION (Technical Division)

Wasinington, D. C.

Plywocd exterior wall finish (Circular Ne.1)............

Wasonite temperad presdwood exterior wall finish

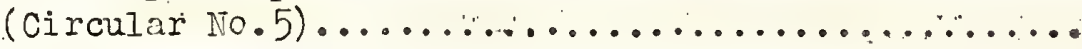

Free

11

Naticnal Iumber Manufacturers' Association

1319-18th. St. No. Wo, Washington, . D. . Co. . .

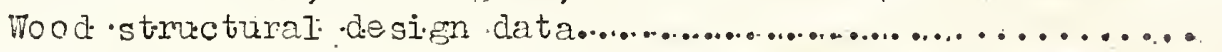

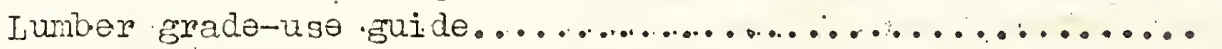

Iumber Iiterature - a bibliography.................

California Rodwood. As sociation

405 kicntzomery st., San Francisco, Ill.

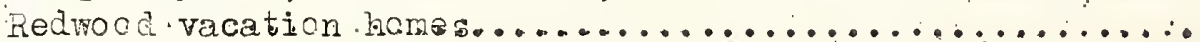

This is redwock.

Free

...............

DCuglas Fir Plywood. Asściation:

Tacoma Bledgs, Tacoma, Wash.

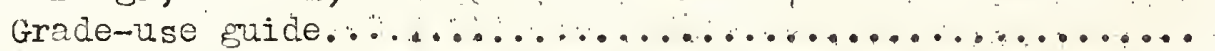

Susge sted. specificaticns, for. Douktas fir.plywood...........

Free

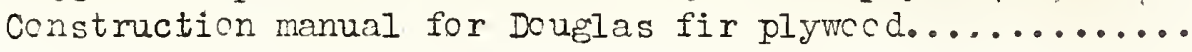

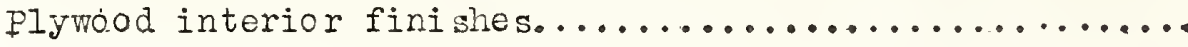

11

II 
Northern Hemlock and Hardwcod Manufacturers' Asscciation

Oshizc sh, Tis.

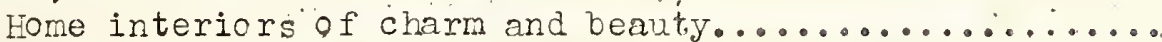

Free

Southern 'Cyp'éss Manufacturers' Association

Bamett Naticnal Bank Bldg. Jackscnvilie, Fla.

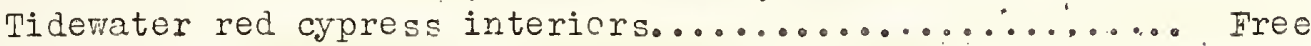

An inside story of Tidewater red cypress.............."

Southern Hardwo à Producèrs, Inc.

Sterick Bldg., Memphis, Tenn.

Scuthern hardwood intericrs..................... Free

'Southern Pine Association

Canal Bldg., New Orleans, I a..

Southern pine manual of standard wood construction...... \$1.00

West ccast. Lumbermen's Associatiçn

364 stuart Blds., Seattle, Wash. .

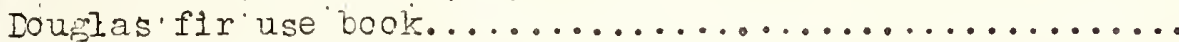

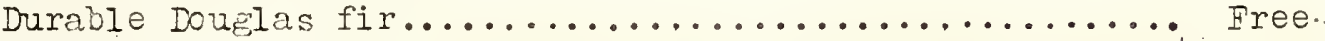

The ri ght use of lumber grades in home constructicn....." "

Western Fine Asscciation

Yeon BIdg.', Portlaind, Ores.

vacaticn cabins built with $10 \mathrm{~g}$ cabin siding.......... 5 cents

\section{MISCELIAINEOUS}

DEPARTMENT OF AGRICUITUPY

Washington, D. C.

Protection of log cabins, rustic work and unseasoned wood from injurious insects (F.armers' Bulletin No.1582)..

Making cellars dry (Farmers' Bulletin ivo.1572)......... 5 " "

Farm drainage (Famers! Builetin Ne.1606):........... 5."

Subterranean térmites and their.control

(Farmer's Bulletin No.1911).....................

DEPARTMEIT OF COMERCE (Naticnal Bureau of Standards)

Washington, D. C.

Standards and specificaticns for building ard construction materials, fixtures, supplies, and equipment

(Ic 619$) \ldots \ldots \ldots \ldots \ldots \ldots \ldots \ldots \ldots \ldots \ldots . \ldots \ldots$ Free

Bullding materials, buildinf standards, hone builing:

Publications of the National Bureau of Standards

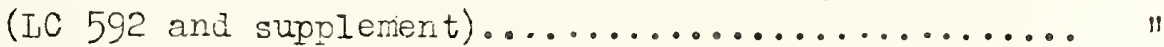

fiesearch on building materials and structures for use

in $10 w-c o s t$ housing $(B M S-1) \ldots \ldots \ldots \ldots \ldots$ cents

A glossary of housing terms (BMS-91).................. 15 u

Structural, heat-transfer, and water-permeability

properties of five earth $\rightarrow$ wall constructicns (BNS-78) $20 \mathrm{n}$

Homo geneous fiber wallbcard (cS 112-43)............ 5 "

Wcod-slat venetian blinds (CS $61-37) \ldots \ldots \ldots \ldots \ldots$ 
FEDERAL HOUSING ADMINISTRATION (Technical Divisicn)

Washington, $\cdot D^{\prime} \cdot C$. '

Protection against temites (Circular No.2)........... Free

FEDERAL SECURITY AGEICY (Fublic Health Service)

Washingten, $D_{0} \cdot C_{0} \ldots \ldots \ldots \ldots \ldots$

The rat and ratpref construction of buildings

('Supplement No.131)

Free

DEPARTMENT OF TEE INTERIOR (Fish and Mildife Service) .

Washington; $D_{0} \cdot C$ :

Homes for birds (Conservation Bulletin I4).

10 cents

kat proofing buildings and premises (Conservation

Bulletin 19).

10

DEDARTMENT OF THE INTERIOK (Office of Indian Affairs)

Chilocco Indian Schcol, Chilocco, Oila.

Earth brick construction...................... 50 cents

Better Home's in America"

Purdue Research Foundation, Tiest Lafayette, Ind.

Dry cellars (Home Information No.12).............. 15 cents

Back-yard playgrounds (Fome Information No.5).......... 15 "

Copper and Brass Re search Assciaticn

420 Lexington Ave., liew York, N. Y.

How to make ycur own screens..................... Free

National Iumber Nanufacturers' Association

1319-18th St. N.W., Washington, D. C.

Exposing the termite...................... Free

Southern. Cypress Manufacturers' Assciation

Barnett Naticnal Bank 31dg., Jacksonvilile, Fla.

Bird-house books:........................... 15 cents

Tidewater red cypress repels terni te attack............ Free 
Alabama ..... Alabama Polytechnic Institute, Auburn

Arizona -.... University of Arizona, Tucscn'

Arkansas. ...... University of Arkan'sas, Fayetteville

Cálifornia....... University ef California," Berizeley

Colorado......... State Asricultural Collége ć Cólcrado, Ft. Collins

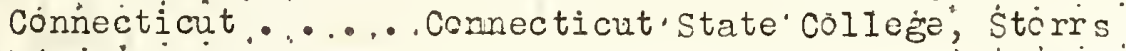

Délawăre. ......University of'Delawáré, "Nèwark

Florida $\therefore . .$. University of Florida; Gainesvilie

Georgia ......University of Georgia; Atheris

Idaho $\because . . .$. Universi.ty of Idalo; íc scow

'IlIincis. : * Universi.ty of Illincis, Urbana

Indiana : : . Eurdue University, Lafayette

Iowa. : : : : Iowa. State Collegé, Ames

Kansás: : : : - Kansas State College; Manhattan

Kentucio: : : : Univeraity of Kentucky; Iexington

Iouiśiana : : Iouisiana State University, Baton Rouge

Maine. : : : University of Maıne, Orono

Maryland: : " University of Marylánd, college Park

Massachusetts . . Massachusetts State Collegë, Ainherist

Michigan., -. . Michigan State "Colle ke; Eiast Iansing".

Mininéso'ta' .... University of Mininesota, 'Univiersity. Farm, St. Paul

Mississippi........Mistisstopi state Collége, State College

Missouri........ University of Mis'scuri, cólumbia

Montana . . - Mcntana State Coliege, Bozeman

Nebrasiza. . . University of Nebraska, Iincoln

Nevada. . . . University of Nevada, Reno

New Hampshire. - University of New Hampshire, Durham

New Jersey... . Kutgers University, New Brmnswick

New Mexico... ... New Mexico State Colilégé, 'state Colliege

New York. . ... Cornell University, I thacá

North Carolina. . University cf Nơt"h Cárolina, State College Sta., Raleigh

North Dakota. ... North Dakota Arricultural Cóliege, Farğo.

Ohio. . . . . Oric. Stane University; Columbris

Orlahoma. . . . Orlarona A: co M. Ccllege, Stiliwater

Oregon. - . - Oregon. State colieše, Corvális

Pennsylvania. - Penur vania state Cóllege, State ccilege

Rino de Island... Rhode Island State College, iringston

Scuth Carolina. - Clemson Gollege, Clemscin

South Dakota. - . South Dakota.State College; Brockings

Tennessee.. . . University of Tennessee, Kncxilile

Texas - . . . A. « M. Gcllege of Texás, college Station

Utah. . .... Utah State Colleg̈e; Iic gan

Vermont .... University of Vermont, Burlington.

Virginia. . .. Virginia Polytechnic Institute, Biacksburs.

Washington. ..... State.college of Washingtin, Pullman

West Virginia ... West Virsinia University, No p̧antów!

Wisconsin .... University of Wisconsin, Madi son

Wyomins ..... University of Wyoming; Iaramie

See Eage I, sẹcond paragraph. - 
Adobe . . . . . . . . . . . . 31,32

Air conditioning. . . . . . . . . . . . . . . . . . . 11, 12

Brick . . . . . . . . . . . . ............ 3

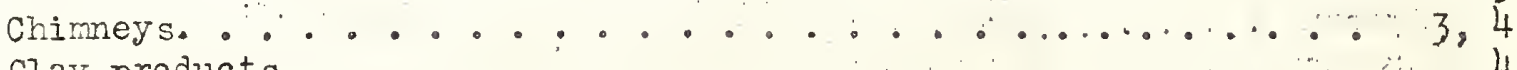

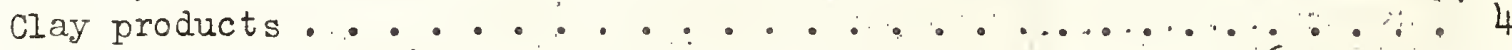

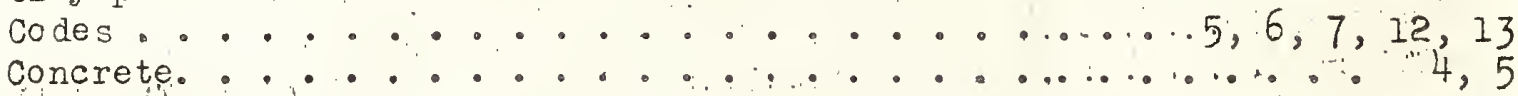

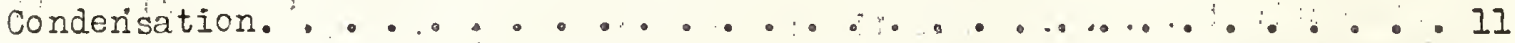

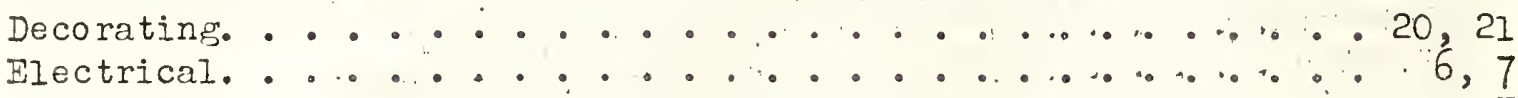

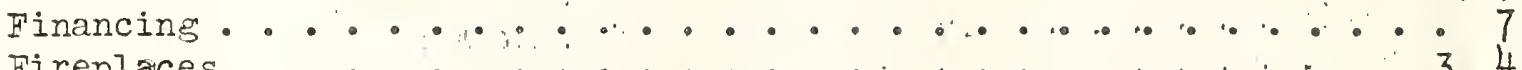

Fireplaces . . . . . . . . . . . . . . . . 3,4

Fire prevention and fire protection ............ . . . 8

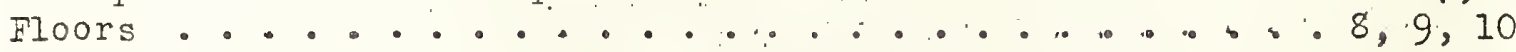

Garage construction . . . . . . . . . . . . . . . 10

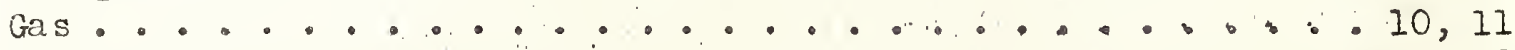

Heating . . . . . . . . . . . . . . . . . . . . 11, 12

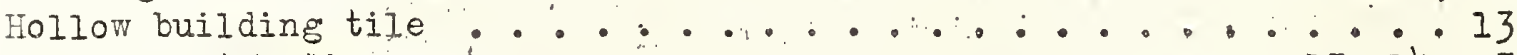

House construction .................................. 14,15

House maintenance and modernization . . . . . . . . . . 15, 16

Household helps . . . . . . . . . . . . . . . . 16, 17

Insulation, tiernal ............................ 18

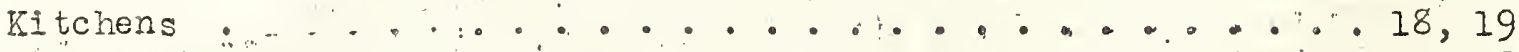

jandscaping . . . . . . . . . . . . . . . . . . . . . 19

Iumber . . . . . . . . . . . . . . . . . . . 30,31

Miscellaneous: Bird houses, building materials and

standards, cellars, drainage, glossary housing terms,

vacation cabins, Services of the National Bureau o.f.

Standards to the home building industry. and to the.

household; playgrounds, rammed-earth walls, screens,

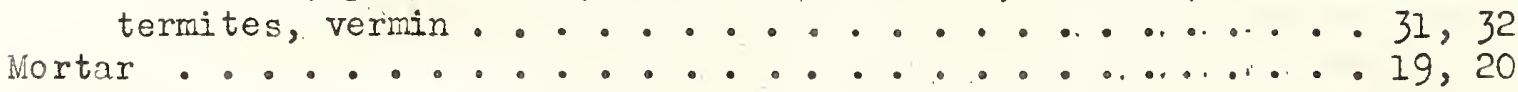

Painting. . . . . . . . . . . . . . . . . . . . 20,21

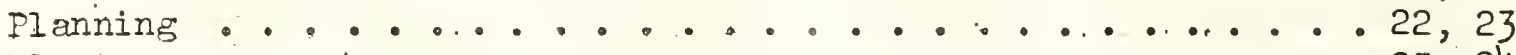

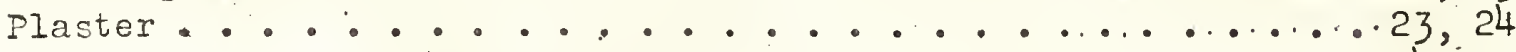

Plumbing . . . . . . . . . . . . .............. 24

Porcelain enamel products . . . . . . . ........... 25

Publications, how obtained. . . . . . . .......... . . I

Refrigeration . . . . . . . . . . . . . . . . . 26

Repairs, house. . . . . . . . . ....... 1 15,16

Roofing . . . . . . . . . . . . . . . . . . 26, 27

Sewage disposal . . . . . . . . . . . . . . . . 27,28

Sewer pipe. . . . . . . . . . . . . . . . . . . . . 4

Soundproofing : . . . . . . . . . . ........... . . . 18

State Agricultural Colleges and Experiment Stations......... 33

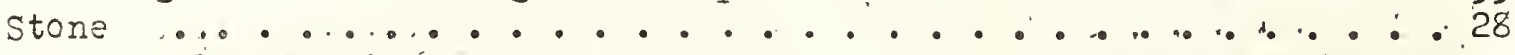

Structural clay tilé . . . . . . . . . . . . . ..... 13

Stucco . . . . . . . . . . . . . . . . . . 23, 24

Ventilating . . . . . . . . . . . . . . . . . 11,12

Tall tile (clay). . . . . . . . . . . . . . . . 4

Talks...................... . . . . . . . . . . . 10

Waterprocfing ................... . . . . 13, 20, 23

Water ......................... . . . . . . . . 28,29

Wood ....................................... 31 